BNWL - 30

\title{
PRECIPITATE PARTICLES IN DILUTELY ALLOYED URANIUM
} QUANTITATIVE METALLOGAPHY

\section{DEVELOPMENI} REPORT

\author{
JANUARY, 1965
}
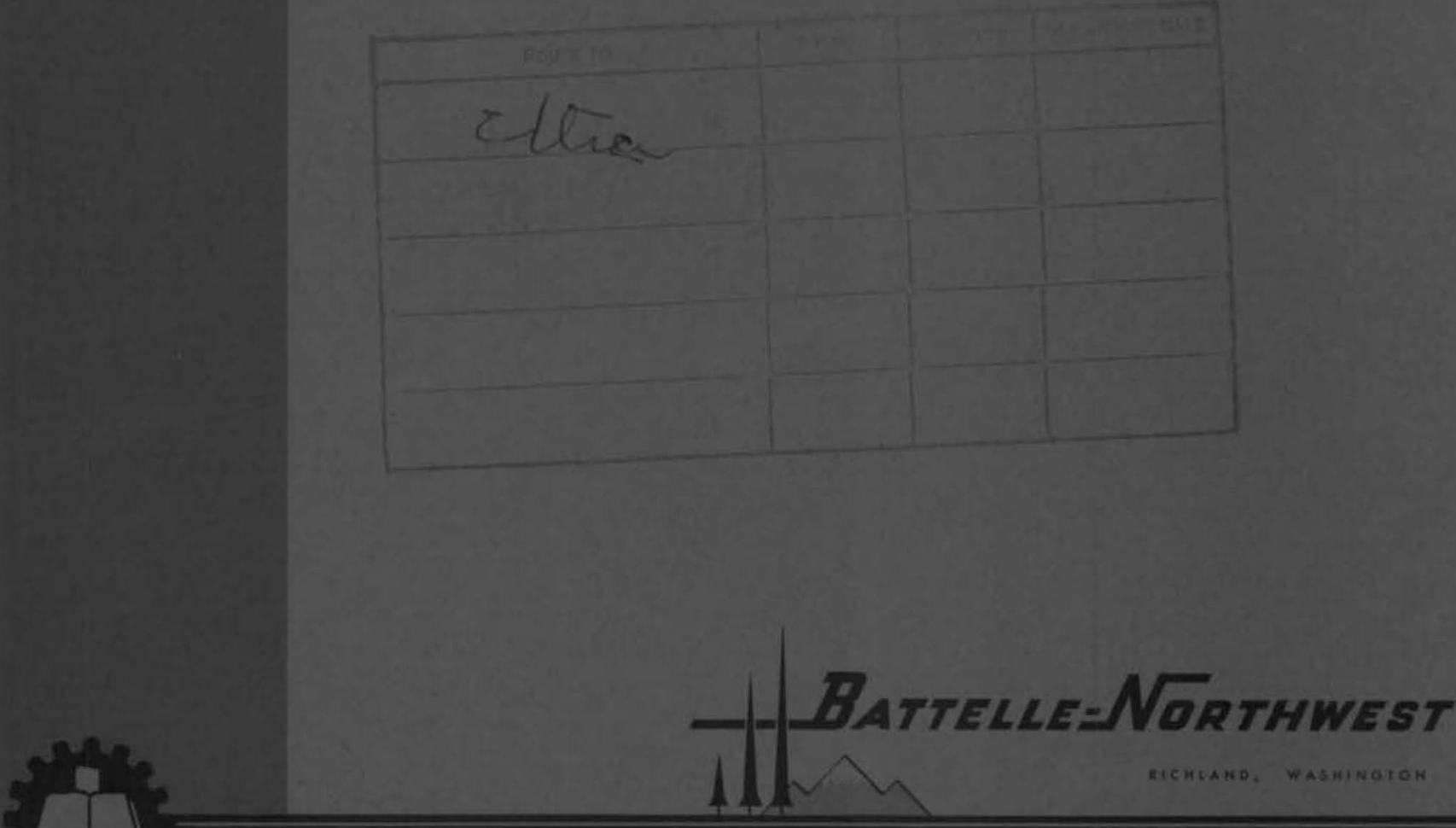


\section{LEGAL NOTICE}

This report was prepored as an account of Government sponsored work. Neither the United States, nor the Commission, nor any person acting on behalf of the Commission:

A. Makes any warranty or representation, expressed or implied, with respect to the accuracy, completeness, or usefulness of the information contained in this report; or that the use of any information, apparatus, method, or process disclosed in this report may not infringe privately owned rights; or

B. Assumes any liabilities with respect to the use of, or for damages resulting from the use of any information, apparatus. method, or process disclosed in this report.

As used in the above, "person acting on behalf of the Commission" includes any employee or contractor of the Commission, or emplayee of such contractor, to the extent that such employee or contractor of the Commission, or employee of such contractor prepares, disseminates, or provides access to, any information pursuant to his employment or contract with the Commission, or his employment with such contraclor.

\section{PACIFIC NORTHWEST LABORATORY}

RICHLAND, WASHINGTON

Operated By

BATTELLE MEMORIAL. INSTITUTE

For The

U. S. ATOMIC ENERGY COMMISSION Under Contract No. AT(45-1)-1830 
BNWL-30

UC-25, Metals, Ceramics, and Materials

PRECIPITATE PARTICLES IN DILUTELY ALLOYED URANIUM QUANTITATIVE METAL LOGRAPHY

By

K. N. Woods

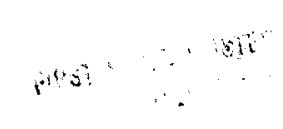

Y. E. Smith

R. D. Leggett

Metallurgy Research

Reactor and Material Technology

January, 1965

PACIFIC NORTHWEST LABORATORY

RICHLAND, WASHINGTON 
Printed in USA. Price $\$ 2.00$. Available from the Clearinghouse for Federal Scientific and Technical Information, National Bureau of Standards,

U. S. Department of Commerce, Springfield, Virginia 


\section{PRECIPITATE PARTICLES IN DILUTELY ALLOYED URANIUM}

QUANTITATIVE METALLOGRAPHY

\section{INTRODUCTION}

This report describes a quantitative metallographic technique for studying the size distribution of micron and submicron second-phase particles present in dilute, uranium-base alloys. Some results on several alloy specimens that had been heat-treated to modify the distribution of second-phase particles are also reported. The size and distribution of second-phase particles are believed to influence drastically the mechanicalphysical properties and the irradiation resistance of uranium and its alloys. Unfortunately, standard techniques have not been developed for readily determining these distributions.

Recent data $(1,2)$ have indicated that relatively low concentrations of alloy additions can markediy improve the behavior of uranium during irradiation. Why and how such additives are effective, however, are largely matters for conjecture. It is generally felt that the benefits are derived from the fact that the additions are largely insoluble in alpha phase uranium and form finely dispersed second-phase particles if the material is appropriately heat-treated. The additives present in solid solution, however, must also be considered. Experimental techniques and data are needed for unambiguous evaluation of the role of additives in uranium. Although the size distribution of second-phase particles is difficult to determine, it may well be the most important single variable that affects irradiation stability. The present study was initiated to characterize the preirradiation state of uranium specimens. Alloys of iron and silicon were selected for initial study. The techniques evolved in this study will be modified to provide postirradiation data as well.

\section{SUMMARY AND CONCLUSIONS}

An electrolytic etching technique for delineating the precipitated second-phase in unirradiated dilute uranium-iron-silicon alloys was investigated. Particles revealed in 15000X electron micrographs of 
negative replicas were measured on a Zeiss Particle Size Analyzer. This information was used to estimate the total density, volume fraction, and size distribution of the precipitate particles. Three independent methods of calculation were applied to determine the distribution curves. These studies lead to the following conclusions.

- An electrolytic etching technique shows promise for delineating second-phase precipitate particles of 0.1 to $1 \mu$ in dilute alloys of uranium.

- A U-180 ppm Fe-90 ppm Si alloy reacts to solutionizing and precipitation treatments in accordance with established theories and published solubility data.

- The peaks of the particle size distributions of some specimens can only be revealed by reducing the resolution point from approximately $0.1 \mathrm{H}$ to $0.02 \mathrm{u}$ or less.

- Additional developmental effort is required to apply the etching techniques to irradiated uranium.

- The three numerical methods used to analyze the particle size data yielded similar but not identical three-dimensional distributions. Selection of the most suitable method requires additional study.

\section{EXPERIMENTAL PROCEDURE}

\section{Materials}

Three uranium-iron-silicon alloys were prepared. Composition A was high-purity dingot uranium, containing approximately 45 ppm iron and 20 ppm silicon, Compositions $\mathrm{B}$ and $\mathrm{C}$ were obtained from high-purity dingot, with additions, to provide final levels of approximately $100 \mathrm{ppm}$ iron and $50 \mathrm{ppm}$ silicon, and $180 \mathrm{ppm}$ iron and 90 ppm silicon, respectively. The uranium in the form of alpha-rolled rod, approximately $1.5 \mathrm{in.} \mathrm{diam,}$ was obtained from Mallinkrodt Chemical Works. The analyses of specimens taken from the rod stock are presented in Table I. 


\section{TABLE I}

SPECTROCHEMICAL IMPURITY LEVELS, ppm, DETERMINED AT

BATTELLE-NORTHWEST

\begin{tabular}{|c|c|c|c|c|c|c|}
\hline & & $\mathrm{A}$ & & & & \\
\hline & Top & Bottom & Top & Bottom & Top & Bottom \\
\hline Iron & 45 & 44 & 110 & 105 & 180 & 190 \\
\hline Silic on & 18 & 21 & 50 & 54 & 95 & 92 \\
\hline Nickel & 5 & 5 & 1 & 1 & 10 & 10 \\
\hline Carbon & 13 & 24 & 9 & 9 & 19 & 15 \\
\hline Nitrogen & 11 & 14 & 10 & 13 & 10 & 12 \\
\hline Hydrogen & & & & & & \\
\hline
\end{tabular}

Metallurgical Treatment

Heat treatments were designed to fulfill two particular requirements:

- Bring the elemental components of the intermetallic secondphase into solution in the matrix.

- Precipitate the intermetallics as a finely dispersed secondphase.

Three solutionizing treatments were employed: A, $7 \mathrm{hr}$ at $643 \mathrm{C}$; B, $5 \mathrm{hr}$ at $730 \mathrm{C}$; and $\mathrm{C}, 2 \mathrm{hr}$ at $800 \mathrm{C}$. Two precipitation treatments were used: $\mathrm{A}, 2 \mathrm{hr}$ at $538 \mathrm{C}$ and $\mathrm{B}, 1 \mathrm{hr}$ at $590 \mathrm{C}$. Specimens of each composition were subjected to a complete combination of heat treatments yielding 30 specimens in all. Only 5 have thus far been processed for particle size determination. The first letter in the specimen identification code defines the composition, with A being the pure material, etc. The second letter defines the solution treatment, and the third letter the precipitation treatment. The precipitation treatment was always preceded by one of the solution treatments. The absence of a solution or precipitation treatment designator indicates the absence of that treatment, accordingly.

Solution treatment specimens consisted of 3 in. lengths of alpharolled core with a $1 / 2$ in. hole drilled through the center. Sections of these specimens $3 / 4$ in. thick were subjected to the precipitation treatment. All heat treatments were conducted by suspending the specimens in salt baths with stainless steel hangers. Liquid Heat 810 was used for treatments 
in the alpha range and Nusal was used at the higher temperatures. Specimens were water-quenched after each heat treatment.

Metallographic Preparation

A quarter section of each of the annular shaped specimens was prepared for the metallographic investigation. Initial preparation included silicon carbide grinding through the 600 grit paper. Originally, the final polish for optical metallography was carried out by successively polishing on 5 and $1 \mu$ diamond wheels with a kerosene lubricant and then finishing on a cloth wheel with Linde $B$ abrasive suspended in $2 \%$ chromic acid. Later however, it was learned that three successive syntron polishing operations using (1) Linde A suspended in 2\% chromic acid on Metcloth, (2) Linde A suspended in 2\% chromic acid on Microcloth, and (3) MgO suspended in distilled water on Microcloth, yielded a better surface. Optical micrographs were taken using polarized light and bright field illumination after samples had been electrolytically etched in a solution of 5 parts ethylene glycol, 5 parts phosphoric acid, and 8 parts ethyl alcohol.

The preparation of specimens for electron microscopy underwent several stages of development. Attempts were made to prepare the specimen surface by (1) vacuum cathodic etching and (2) electrolytic polishing and etching. Attempts were made to replicate the specimen surface with (1) collodion, (2) Formvar, and (3) cellulose acetate. Collodion and Formvar were unsuccessful since collodion did not wet the surface and Formvar was not strong enough to be successfully stripped. Cellulose acetate replicas were stripped successfully and were used to make negative, $\mathrm{UO}_{2}$ shadowed, carbon substrates which were used exclusively for the electron microscope investigation.

The vacuum cathodic etched specimens exhibited a high density of artifacts, believed to be surface redeposition of uranium metal. The artifacts which had somewhat the appearance of a second-phase appeared in much greater quantity than could possible have been attributed to secondphase. Also, the cathodic etching technique resulted in very poor contrast between the particles believed to be $\mathrm{U}_{6} \mathrm{Fe}$ and the matrix. However, the 
recent acquisition of new cathodic etching apparatus has resulted in improvements in this area and efforts are currently underway to cathodically etch these alloys.

Electrolytic polishing and etching was developed for electron microscopy using the same solution as for optical microscopy, which incidently has been used at NMI. ${ }^{(3)}$ The solution consists of 5 parts ethylene glycol, 5 parts of ortho phosphoric acid, and 8 parts ethyl alcohol. The initial effort consisted of electropolishing at $18 \mathrm{~V}$ for $5 \mathrm{sec}$, followed by electroetching at $5 \mathrm{~V}$ for $15 \mathrm{sec}$. Samples etched in this manner had a very coarse background when viewed at 15,000X, and very small precipitate particles could not be distinguished from the granular appearing matrix. In an effort to eliminate the background structure which had the appearance of flowed metal, it was decided to increase the polishing and etching periods. It was finally concluded that three cycles of treatment, each cycle consisting of $18 \mathrm{~V}$ for $60 \mathrm{sec}$ followed by $5 \mathrm{~V}$ for $120 \mathrm{sec}$, resulted in the most satisfactory surface that was obtainable with this etchant for specimens of this geometry. A fourth cycle yielded no significant improvement. Although fine particle resolution was considerable improved by the developmental efforts, the texture of the matrix continued to exhibit significant sample-tosample variation. This problem has not been completely eliminated and is, therefore, added justification for further work with cathodic etching.

\section{Quantitative Measurements}

Electron micrographs were taken of 12 randomly chosen areas of each specimen, These micrographs were enlarged to about 18 by $18 \mathrm{~cm}$ at $15,000 \mathrm{X}$ and printed on semitransparent paper. The precipitate particles were counted on each of the 12 micrographs of each specimen with the aid of a Zeiss Particle Size Analyzer. Figure 1 shows the analyzer being used. Figure 2 is a schematic diagram of the analyzer. With this device, a circle of light which is continuously variable in size is matched to the size of the particle being counted. When the spot of light is properly matched, the depressing of a foot switch by the operator records the presence of a particle within a size range (called a cell) which 


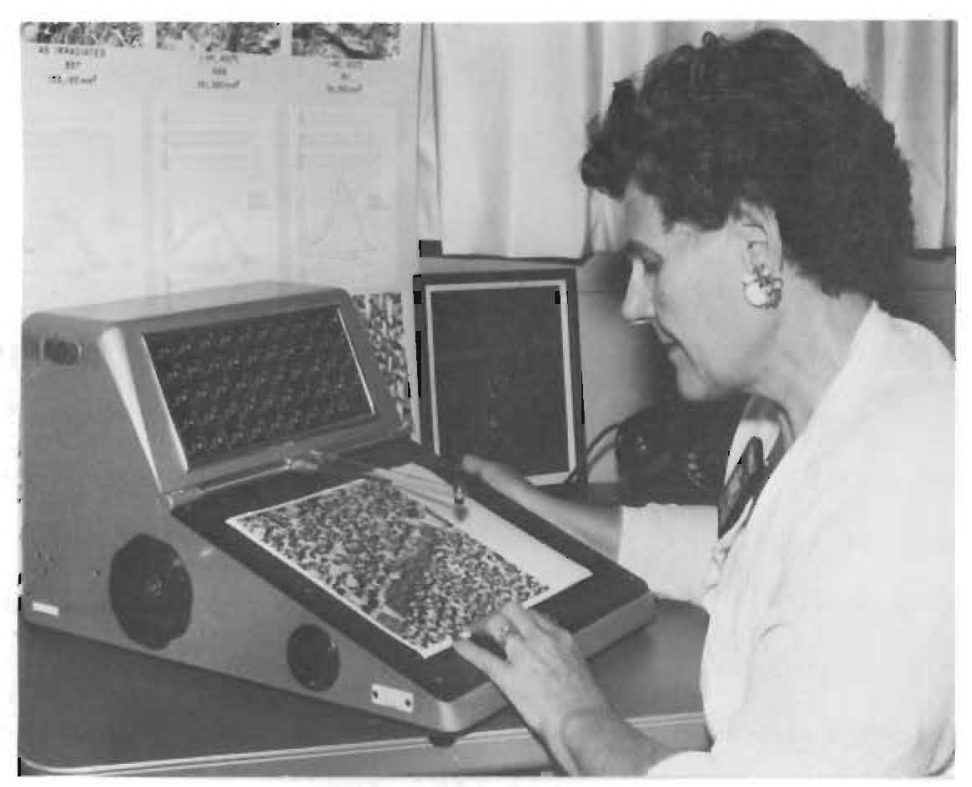

FIGURE 1

Ziess Pore and Particle Size Analyzer Being Used to Measure Pores

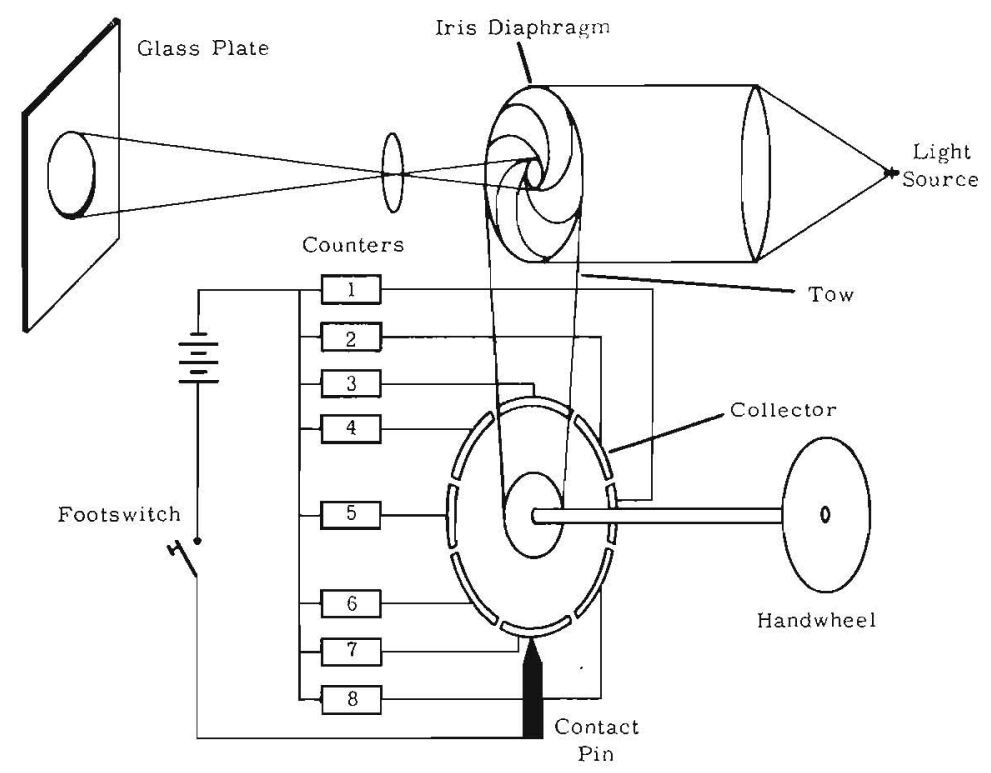

FIGURE 2

Diagrammatic Sketch of Particle Size Analyzer 
includes the size of the spot of light at the time the counter is actuated. The particle size range in each cell is determined by an adjustment of the analyzer which is made before the counting operation is begun. As the presence of the particle is being registered on the counter in the appropriate cell, a small hole is simultaneously punched through the electron micrograph at the center of the light spot. The hole is an indication to the operator that the particle has been counted. It should be noted that the spot of light may be matched to the particle according to one of the following two criteria: (1) match the periphery of the spot to the maximum dimension of the particle, or (2) match the area of the spot to the estimated area of particle. Since the precipitate particles were fundamentally spherical, the matching of areas was used exclusively. This approach minimizes the bias in the areal estimate of volume fraction of precipitate.

The analyzer has 48 individual cell counters, and these may be distributed over the total particle size range according to either a linear or an exponential function, depending upon the setting of a switch on the instrument. Mathematically, the diameter within any given cell is related to the cell number by one of the two following functions:

(1) $D=a z+b$

(2) $D=e^{c z+d}$

where

$\mathrm{D}=$ mean diameter within cell $\mathrm{z}$

$\mathrm{z}=$ cell number ( 1 to 48 )

$\mathrm{e}=$ base of natural logarithms

$a, b, c$, and $d=$ constants of the instrument; $b=e^{d}$, the nonzero resolution point.

The constants are adjusted such that lower and upper diameter limits coincide. The diameter increment per cell is the same for either mode of operation in Cell 31. The exponential relationship between particle diameter and cell number, of Equation (2) above, has the advantage of allowing much greater resolution of the particle size distribution in the fine particle region. Since this region is of primary interest, the exponential distribution of particle size measurements was used exclusively in this work on dilute uranium alloys. 


\section{Quantitative Metallographic Calculations}

The data obtained with the analyzer consist of the distribution of second-phase particle interface diameters as they appear in the electron micrograph of the $\mathrm{UO}_{2}$ shadowed, negative, carbon replica. A number of assumptions and mathematical operations are necessary for an estimate of the size distribution of second-phase particles in the three dimensional matrix.

It is also worthwhile to calculate the volume fraction of particles present, as a rough check on the particle density calculation. It should be kept in mind, however, that this second calculation may have marginal value, only. Although the density of the very fine particles may be of greatestsignificance in improving the irradiation behavior of uranium, these small particles may constitute only a small part of the total volume fraction.

It is assumed that all particles are spheres, that etching causes no alteration of the particle interface diameter, that replication is perfect, and that particles are randomly distributed throughout the matrix. Suppose that $n_{i}$ particles of true radius, $r_{i}$, intersect the interface of area, $A$. These particles must have their centers within distance $r_{i}$ of the interface.

Therefore, the volume of matrix sampled is $\mathrm{A} \times 2 \mathrm{r}_{i}$, as shown in Figure 3 . The true density of particles, pd, in cell $i$ of radius $r_{i}$ is

$$
\begin{aligned}
\mathrm{pd}_{i} & =\frac{\text { Number of Particles }}{\text { Volume of Matrix }} \\
p d_{i} & =\frac{N_{i}}{A \times 2 r_{i}}
\end{aligned}
$$

Therefore, the total particle density, FD, for particles of all $\mathrm{k}$ size ranges which intersect the interface is

$$
\mathrm{PD}=\sum_{i=1}^{\mathrm{k}} \quad \mathrm{pd}_{\mathrm{i}}=\sum_{i=1}^{\mathrm{k}} \frac{\mathrm{n}_{\mathrm{i}}}{\mathrm{A} \times 2 \mathrm{r}_{\mathrm{i}}}
$$




$$
P D=\frac{1}{2 A} \sum_{i=1}^{k} \frac{n_{i}}{r_{i}} .
$$

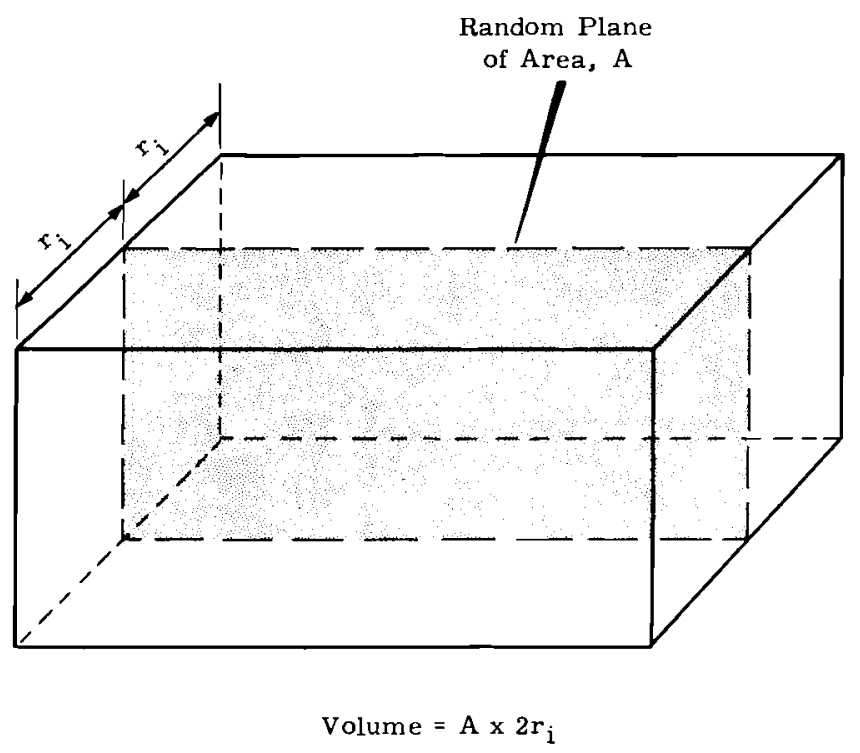

FIGURE 3

Sampled Volume of Matrix Which Contains Particles of Radius, $r_{i}$, Which Form Interface Radii, $r_{0}$, at Intersection

With Randomly Located Surface

A similar equation can be obtained for the volume fraction of second-phase particles. The volume fraction taken up by particles of true radius, $r_{i}$, is

$$
\begin{aligned}
v_{i} & =\frac{\text { Volume of Particles }}{\text { Volume of Matrix }} \\
v_{i} & =\frac{\left(4 / 3 \pi r_{i}^{3}\right) n_{i}}{A 2 r_{i}} \\
& =\frac{2 \pi}{3 A} n_{i} r_{i}^{2} .
\end{aligned}
$$


The total volume fraction of all particles which intersect the interface is, therefore,

$$
V F=\frac{2 \pi}{3 A} \sum_{i=1}^{k} n_{i} r_{i}^{2}
$$

Since the equations developed above are in terms of true particle radii, it is necessary to obtain a relationship between the true radius, $r_{i}$ and the observed interface radius, $r_{o i}$. Based on probability theory, a development by Nicholson provides the needed relationship. (4) Some basic information must be considered to follow this development.

Consider the random variable, $x$, which, generally speaking may take on either a finite or infinite range of values. The probability of occurrence of each value of $x$ may be represented by some function, $p(x)$, in Figure 4.

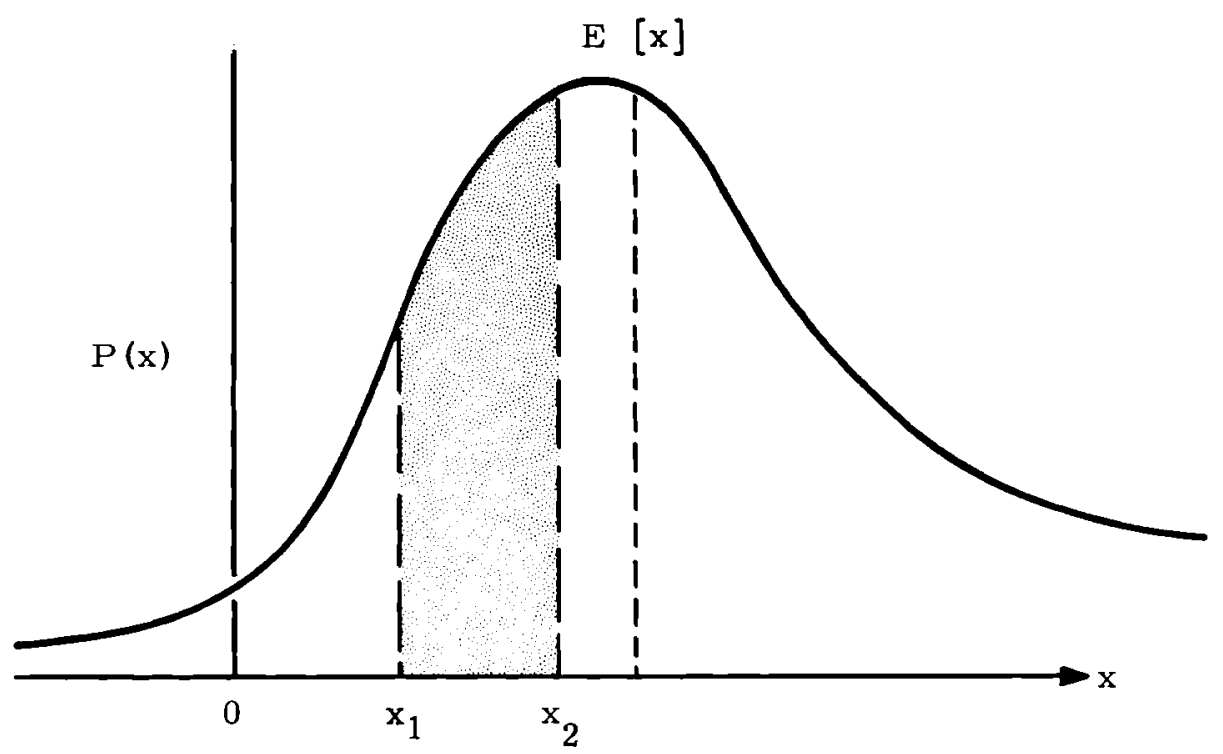

FIGURE 4

Probability Density Function, $P(x)$, for the Random Variable, $x$, with Expected Value, E (x) 
If the integral of $\mathrm{p}(\mathrm{x})$ over the range $\mathrm{x}_{1}$ to $\mathrm{x}_{2}$ is equal to the probability of $x$ occurring between $x_{1}$ and $x_{2}$, then $p(x)$ is the probability density function for $x .{ }^{(5)}$ Accordingly, the integral of $p(x)$ over the total range of $x$ is

$$
\int_{-\infty}^{\infty} p(x) d x=1 \text {. }
$$

It is also true that the average value of the random variable, $x$, will be given by

$$
E[x]=\int_{-\infty}^{\infty} x p(x) d x .
$$

This average value, $\mathrm{E}[\mathrm{x}]$ is, by definition, the expected value of the random variable, $x$. It is equal to the center of gravity of the area under the distribution curve, along the $\mathrm{x}$ axis. More generally, the expected value of $\mathrm{x}^{\mathrm{N}}$ is

$$
E\left[x^{N}\right]=\int_{-\infty}^{\infty} x^{N} p(x) d x .
$$

The above background material will now be applied to the problem of passing a plane through a sphere at random. Consider the plane interface, S, passing through the sphere of Figure 5 at a distance, D, from

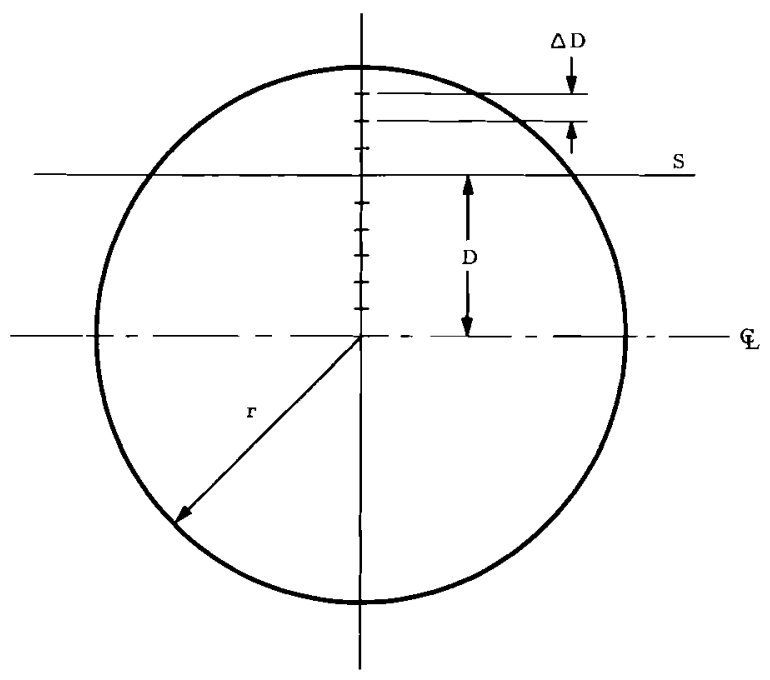

FIGURE 5

Random Plane of Intersection, S, Passing Through Sphere of Radius, $r$, at Distance, D, from Center 
the center. Since the sphere is symmetric, the same answer will be obtained if only the upper half is considered. It the total range of $D$, which varies from 0 to $r$, is divided into equal increments, $\Delta \mathrm{D}$, then it is equally probable that $\mathrm{S}$ will pass through any one of these increments, i.e., the probability density function of $D, p(D)$ is a constant. Because

$$
\int_{0}^{r} p(D) d D=1,
$$

then

$$
p(D)=\frac{1}{r}
$$

Since we are interested not in the distance of the plane from the center, but in the resulting interface radius $r_{0}$, it is necessary to obtain the probability density function for $r_{0}, p\left(r_{o}\right)$. From probability theory, again, it is true that

$$
p\left(r_{0}\right)=p(D)\left|\frac{d D}{d r_{0}}\right|
$$

and

$$
\begin{gathered}
\mathrm{D}=\sqrt{\mathrm{r}^{2}-\mathrm{r}_{\mathrm{o}}^{2}} \\
\frac{\mathrm{dD}}{\mathrm{dr}}=-\frac{\mathrm{r}_{\mathrm{o}}}{\sqrt{\mathrm{r}^{2}-\mathrm{r}_{\mathrm{o}}^{2}}}
\end{gathered}
$$

therefore,

$$
p\left(r_{o}\right)=\frac{1}{r} \frac{r_{o}}{\sqrt{r^{2}-r_{o}^{2}}} .
$$

It is now possible to find the expected value of $\mathrm{r}_{\mathrm{o}}{ }_{\mathrm{N}}^{\mathrm{N}}$ by

$$
\begin{aligned}
E\left(r_{o}^{N}\right) & =\int_{0}^{r} r_{0}^{N} p\left(r_{o}\right) d r_{0} \\
& =\int_{0}^{r} \frac{r_{0}^{N+1}}{r^{2}-r_{o}^{2}} d r_{0} .
\end{aligned}
$$


Substituting $x=\frac{\mathrm{r}_{\mathrm{O}}}{\mathrm{r}}$, we obtain the expected value of the $\mathrm{N}^{\text {th }}$ moment of the ratio of the interface radius to the true radius,

$$
E\left[\left(\frac{r_{0}}{r}\right)\right]=\int_{0}^{1} \frac{x^{N+1}}{\sqrt{1-x^{2}}} d x .
$$

Making a change in the variable of integration by substituting $t=x^{2}$ results in

$$
\mathrm{E}\left[\left(\frac{\mathrm{O}}{\mathrm{r}}\right)^{\mathrm{N}}\right]=\frac{1}{2} \int_{\mathrm{O}}^{1} \mathrm{t}^{\mathrm{N} / 2}(1-\mathrm{t})^{-1 / 2} \mathrm{dt}
$$

The integral is the complete beta function, defined by

$$
B(u, v)=\int_{0}^{1} t^{u-1}(1-t)^{v-1} d t
$$

therefore,

$$
E\left[\left(\frac{r_{\mathrm{O}}}{\mathrm{r}}\right)^{\mathrm{N}}\right]=\frac{1}{2} \mathrm{~B}\left(\frac{\mathrm{N}+2}{2}, \frac{1}{2}\right) .
$$

Since the above particle density and volume fraction equations were functions of $r^{-1}$ and $r^{2}$, respectively, the expected value equation is evaluated for $\mathrm{N}=-1$ and $\mathrm{N}=2$.

$$
E\left[\left(\frac{r}{r}\right)^{-1}\right]=\frac{\pi}{2}
$$

and

$$
\mathrm{E}\left[\left(\frac{\mathrm{r}}{\mathrm{r}}\right)^{2}\right]=\frac{2}{3}
$$


Therefore, the particle density becomes

$$
\begin{aligned}
P D & =\frac{1}{2 A} \sum_{i=1}^{k} \frac{n_{i}}{r_{i}} \\
& =\frac{1}{2 A} \sum_{i=1}^{k} \frac{2 n_{i}}{\pi r_{o i}} \\
& =\frac{1}{\pi A} \sum_{i=1}^{k} \frac{n_{i}}{r_{o i}}
\end{aligned}
$$

and the volume fraction becomes

$$
\begin{aligned}
V F & =\frac{2^{\pi}}{3 \mathrm{~A}} \sum_{i=1}^{\mathrm{k}} \mathrm{n}_{i} \mathrm{r}_{\mathrm{i}}^{2} \\
& =\frac{2 \pi}{3 \mathrm{~A}} \sum_{i=1}^{\mathrm{k}} \frac{3 \mathrm{n}_{\mathrm{i}} \mathrm{r}_{\mathrm{oi}}^{2}}{2} \\
& =\frac{\pi}{\mathrm{A}} \sum_{i=1}^{\mathrm{k}} \mathrm{n}_{\mathrm{i}} \mathrm{r}_{\mathrm{oi}}^{2} .
\end{aligned}
$$

Due to the limitations of the measuring technique, it is necessary to make one correction in these equations to tailor them to the physical situation. It is not possible to distinguish particles of $\mathrm{r}_{\mathrm{O}}<\mathrm{b} / 2$ from the granular appearing matrix. While, in actuality, the appearance of the matrix varied from specimen to specimen, b was maintained constant as the lower limit of the Zeiss Particle Size Analyzer for the particular magnification involved. Therefore, the sampled volume, for Cell $i$, with average true particle radius, $r_{i}$, should not be $A \times 2 r_{i}$, as discussed originally. With the nonzero resolution point, $b$, the sampled volume is

$$
\begin{aligned}
V & =2 A\left[r_{i}=\left(r_{i}-\sqrt{r_{i}^{2}-b^{2} / 4}\right)\right] \\
& =2 A \sqrt{r_{i}^{2}-b^{2} / 4}
\end{aligned}
$$


This correction may be included in the particle density and total volume fraction equations. However, it is necessary to pass through another beta function integral, similar to the above transformation, to obtain the proper relationship between the true radius, $r_{i}$, of the particles in Cell $i$ and the observed radius, $r_{0 i}$. This transformation, as presented by Nicholson ${ }^{(4)}$, results in

$$
P D=\frac{1}{\pi A} \sum_{i=1}^{k} \frac{n_{i}}{\sqrt{r_{o i}^{2}-b^{2} / 4}}
$$

and

$$
\mathrm{VF}=\frac{\pi}{\mathrm{A}} \sum_{i=1}^{\mathrm{k}} \frac{\mathrm{n}_{\mathrm{i}} \mathrm{r}_{\mathrm{o} i}^{3}}{\sqrt{\mathrm{r}_{\mathrm{oi}}^{2}-\mathrm{b}^{2} / 4}}
$$

The data obtained from the analyzer, which are represented as $n_{i}$ in the above equations, were processed accordingly. The quantities were calculated for each cell and then summed to obtain the total. The individual particle density for each cell when plotted against the particle diameter provides a representation of an estimate of the particle size distribution for the second phase. However, this result is not meaningful to the inexperienced observer since it contains an inherent distortion because the cellular distribution of particle radii was originally chosen as an exponential function. For example, the histogram of particle density versus particle diameter appears as in Figure 6, which is simplified to 10 cells rather than 48 . The height, $\mathrm{H}_{i}$, of each portion of the histogram represents $N_{i}$, the number of particles per unit volume of matrix which presented an observed diameter in the electron micrograph within the limits of Cell $i$. It is desirable to approximate the continuous true distribution curve of Figure 6a from this histogram. If the number, $\mathrm{N}_{i}$, is divided by the cell width in diameter units, the histogram of Figure $6 c$ is obtained. Connecting cell midpoints with a smooth curve 

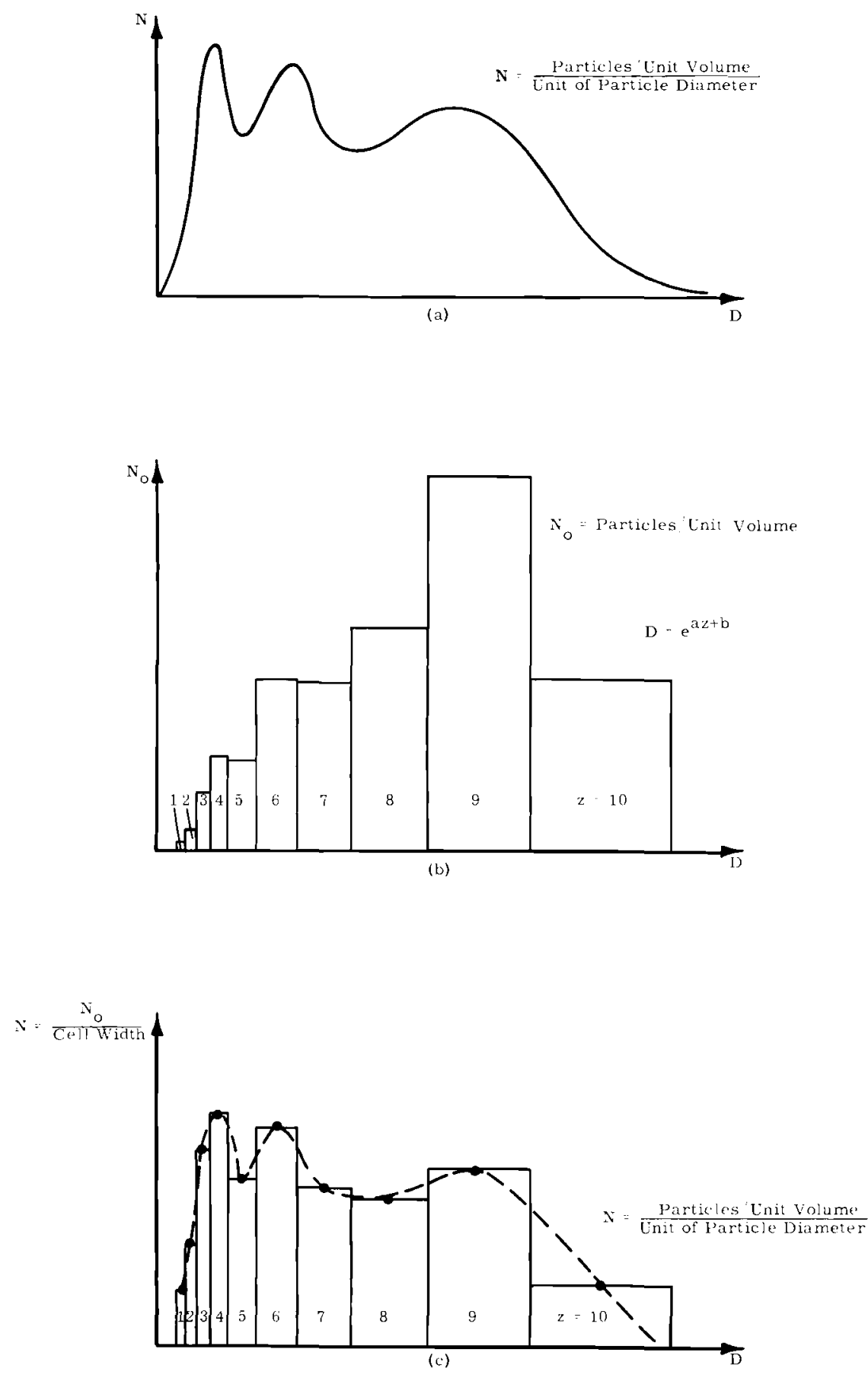

FIGURE 6

Relationship Between Actual Particle Size Distribution Curve (a), and Calculated Curve, (c), Derived from Exponential Distribution of Observed Particle Radii, (b). 
approximates the actual, true distribution of Curve 6a. This resultant curve of Figure 6c has some unique characteristics. The ordinate is $\mathrm{N} / \Delta \mathrm{D}$ in particles per unit volume per unit of particle diameter. If this curve is integrated over the range between any two arbitrary limits, $\mathrm{D}_{1}$ and $\mathrm{D}_{2}$, the result,

$$
N_{\mathrm{o}}=\int_{D_{1}}^{\mathrm{D}_{2}}(\mathrm{~N}) \mathrm{d}(\mathrm{D})
$$

is the approximate number of particles per unit volume which presented observed diameters between $\mathrm{D}_{1}$ and $\mathrm{D}_{2}$. It is obvious that integration over the whole range yields the total particle density. This curve is, therefore, analogous to the probability density functions discussed above in the development of the method. $\mathrm{N}$ is the particle density-intensity of the dispersed second-phase with respect to the observed diameter, rather than the true diameter, of the particle. Theoretically, $\mathrm{N}$ versus $\mathrm{D}$ is shifted to the left of the position it would occupy if the abscissa was true diameter. This effect may be damped out only by integrating over the whole range of the curve to obtain the total particle density.

To obtain information on the validity of the method, as well as gain experience with similar methods developed by other investigators, several other calculations were made. As model specimens for comparison, the dilute uranium alloy specimen for which the most data were available was chosen, along with a specimen of spherodized $1.10 \%$ carbon steel*. Three particle density-intensity curves were calculated for dilute alloy Specimen C (180 ppm iron, 90 ppm silicon, as-alpharolled). In addition to the Nicholson calculation, which was made for all five dilute alloy specimens processed, calculations were made by the Schwartz method and the Johnson-Saltykov method. (5) These three methods were also used on a $1.10 \%$ carbon steel specimen which contained a relatively coarse dispersion of spheroidized carbides revealed on an enlarged optical micrograph at $3000 \mathrm{X}$.

\footnotetext{
* Received from Prof. M. Sinnott of the University of Michigan.
} 
The method of Schwartz assumes randomly distributed spheres and calls for dividing the total range of observed radii into ten linearly distributed cells, i.e., 0 to $0.1 \mathrm{R}, 0.1 \mathrm{R}$ to $0.2 \mathrm{R}, \ldots, 0.9 \mathrm{R}$ to $\mathrm{R}$, where $\mathrm{R}$ is the maximum radius observed. While it is considered possible, or even likely, that the largest particle in the matrix may not be represented, only the far right tail of the distribution will be truncated by considering this observed radius of the largest particle as the largest particle size present. Let the number of spheres per unit volume be

$$
\mathrm{N}_{10}, \mathrm{~N}_{9}, \mathrm{~N}_{8}, \ldots, \mathrm{N}_{1}
$$

for cells having maximum sphere sizes,

$$
\mathrm{R}, 0.9 \mathrm{R}, 0.8 \mathrm{R}, \ldots, 0.1 \mathrm{R} \text {, }
$$

respectively. The number of sections observed per unit area is

$$
\mathrm{n}_{10}, \mathrm{n}_{9}, \mathrm{n}_{8}, \ldots, \mathrm{n}_{1}
$$

Obviously, all cross-sections having radii between $0.9 \mathrm{R}$ and $\mathrm{R}$, i. e., of the cell having maximum size $R$, above, will belong to spheres of size $0.9 \mathrm{R}$ to $R$. Accordingly the spheres in Cell 10 , denoted by $\mathrm{N}_{10}$, can be computed directly from the number, $\mathrm{n}_{10}$, and the probability of cutting a sphere such as to yield a cross-section with its radius equal to 9/10 the sphere radius or greater. The number $\mathrm{n}_{9}$, however, will include sections of spheres between $0.9 \mathrm{R}$ and $\mathrm{R}$, as well as sections from spheres within the cell limits, $0.8 \mathrm{R}$ to $0.9 \mathrm{R}$. Therefore to compute $\mathrm{N}_{9}$, two terms are involved: one to calculate the number of particles which appear to be present and one to subtract the contribution to this number from the next higher cell size. Each successive calculation, therefore, has one additional subtraction term and the density of particles $\mathrm{N}_{i}$, the number of particles per unit volume in the $i^{\text {th }}$ cell is

$$
N_{i}=\frac{A_{i} n_{i}-A_{i+1} n_{i+1}-A_{i+2} n_{i+2}-\ldots A_{10} n_{10}}{2 R}
$$


where the $A_{i}$ are from Schwartz's tabulation of Table II, which is based on the probabilities of obtaining sections of certain sizes by cutting spheres at random.

TABLE II

SCHWARTZ COEFFICIENTS FOR TEN CELL DISTRIBUTION

\begin{tabular}{|c|c|c|c|c|c|c|c|c|c|c|}
\hline & & & & & ficier & $5, \mathrm{~A}$. & & & & \\
\hline & $\mathrm{N}_{1}$ & $\mathrm{~N}_{2}$ & $\mathrm{~N}_{3}$ & $\mathrm{~N}_{4}$ & $\mathrm{~N}_{5}$ & $\mathrm{~N}_{6}$ & $\mathrm{~N}_{7}$ & $\mathrm{~N}_{8}$ & $\mathrm{~N}_{9}$ & $\mathrm{~N}_{10}$ \\
\hline $\mathrm{N}_{10}$ & & & & & & & & & & 2.29 \\
\hline $\mathrm{N}_{9}$ & & & & & & & & & 2.43 & 0.91 \\
\hline $\mathrm{N}_{8}$ & & & & & & & & 2.58 & 0.96 & 0.31 \\
\hline $\mathrm{N}_{7}$ & & & & & & & 2.79 & 1.02 & 0.32 & 0.16 \\
\hline $\mathrm{N}_{6}$ & & & & & & 3.02 & 1.11 & 0.34 & 0.17 & 0.08 \\
\hline $\mathrm{N}_{5}$ & & & & & 3.33 & 1.17 & 0.37 & 0.18 & 0.09 & 0.05 \\
\hline $\mathrm{N}_{4}$ & & & & 3.78 & 1.21 & 0.40 & 0.17 & 0.09 & 0.06 & 0.04 \\
\hline $\mathrm{N}_{3}$ & & & 4.47 & 1.39 & 0.47 & 0.15 & 0.09 & 0.05 & 0.03 & 0.04 \\
\hline $\mathrm{N}_{2}$ & & 5.77 & 1.53 & 0.41 & 0.17 & 0.08 & 0.05 & 0.03 & 0.01 & 0.01 \\
\hline $\mathrm{N}_{1}$ & 10.0 & 1.54 & 0.35 & 0.13 & 0.05 & 0.05 & 0.02 & 0.01 & 0.01 & 0.00 \\
\hline
\end{tabular}

The Johnson-Saltykov method of estimating the three dimensional size distribution of particles from a two dimensional section has one advantage, in particular, with respect to the dilute uranium alloy problem. The method is based on an exponential distribution of particle diameters and therefore, allows greater resolution of the small particle region of the particle density-intensity curve, as in the Nicholson analysis. Only a brief description of the method will be presented here. For a more detailed presentation one should consult the references.

The method is fundamentally the same as the Schwartz, in that particles of the largest cell size are calculated directly from the observed number of interface radii, and all others are calculated by successive 
subtractions. Since the method uses the exponential distribution of cell widths, any number of cells may be used with no change in the tabulated calculation aids. This is in distinct contrast to the Schwartz method where a different table of coefficients is required for each change in the number of cells.

\section{RESULTS}

\section{Optical Metallography}

Optical photomicrographs of some of the specimens included in this study are presented in Figures 7, 8, and 9, as they appear under polarized

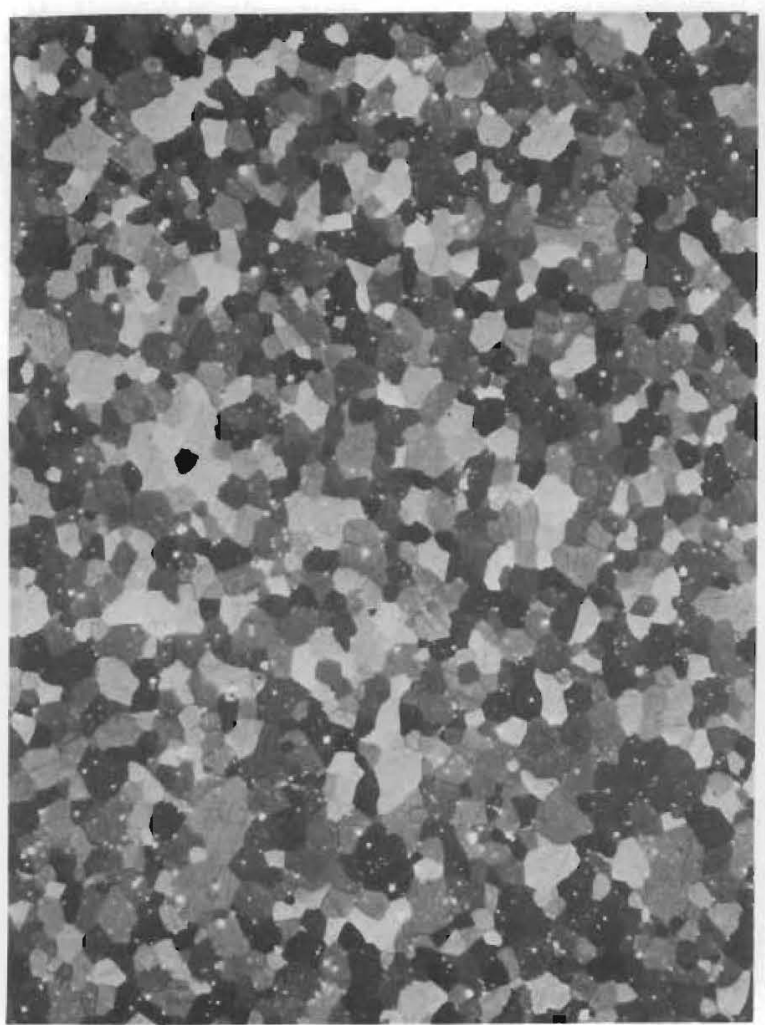

PL

(a) Specimen A

$100 \mathrm{x}$

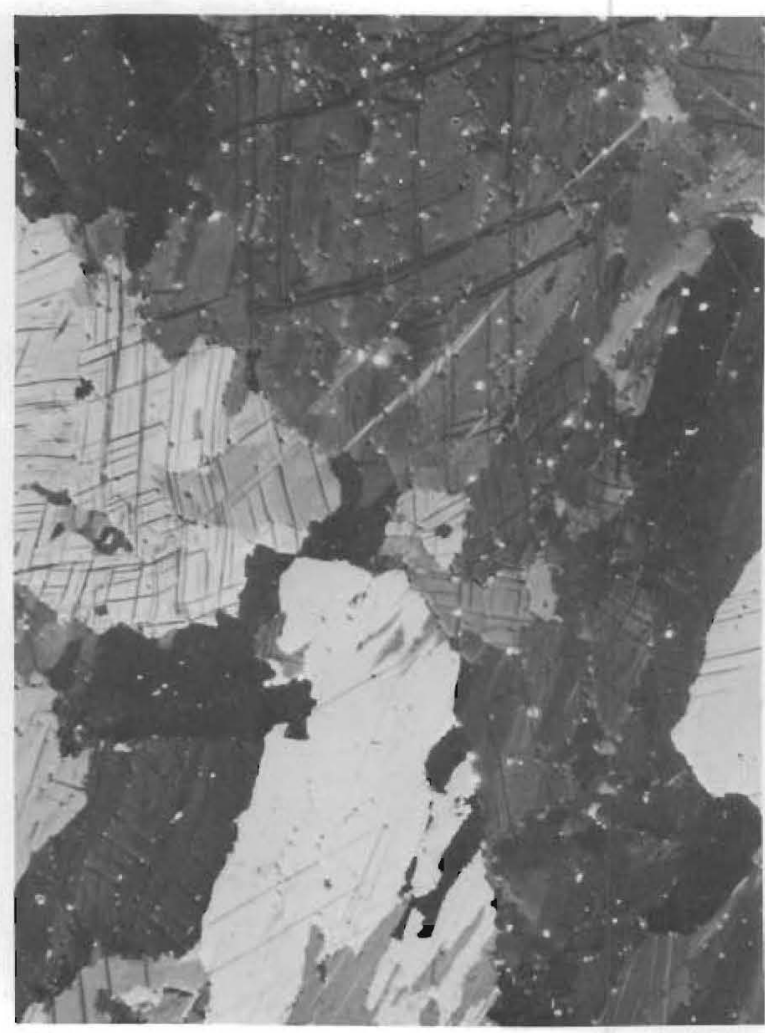

PL

(b) Specimen $A B$

$100 \mathrm{X}$

\section{FIGURE 7}

(a) High Purity Uranium (45 Fe-20 Si) Alpha Rolled

(b) High Purity Uranium (45 Fe-20 Si) Alpha Rolled Plus $5 \mathrm{hr}$ at $730 \mathrm{C}$ 


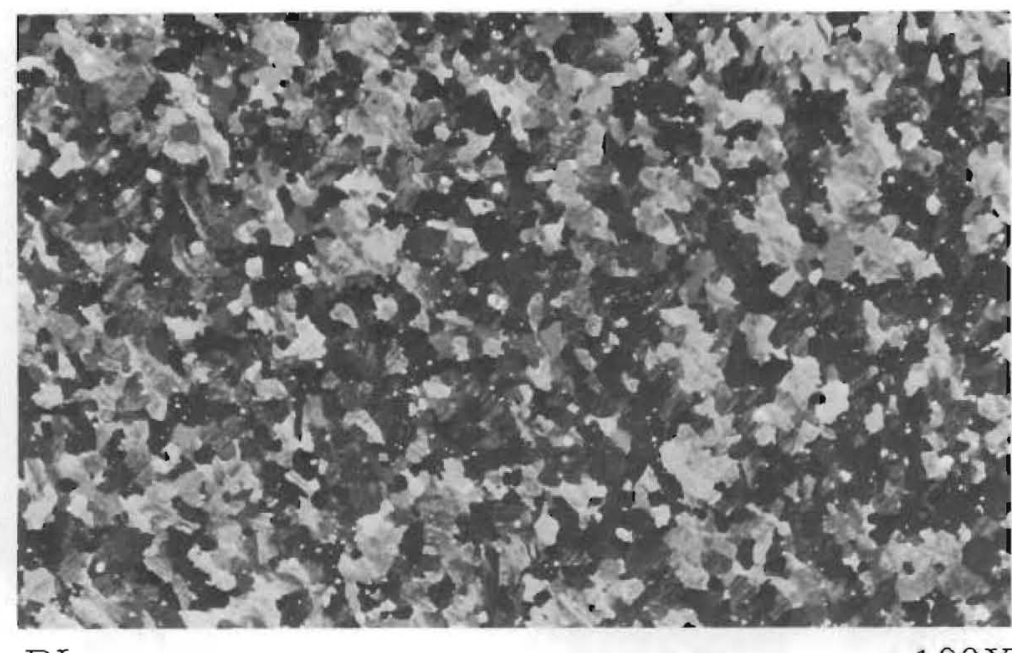
(a) Specimen C

U-180 ppm Fe-90 ppm Si Alpha Rolled

PL

$100 \mathrm{X}$

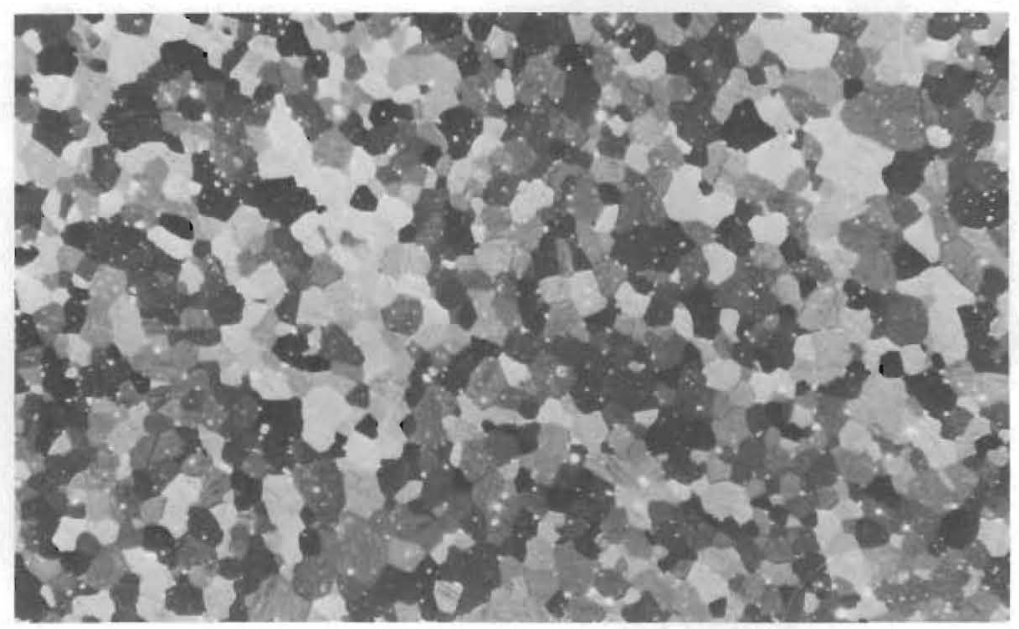

PL

$100 X$

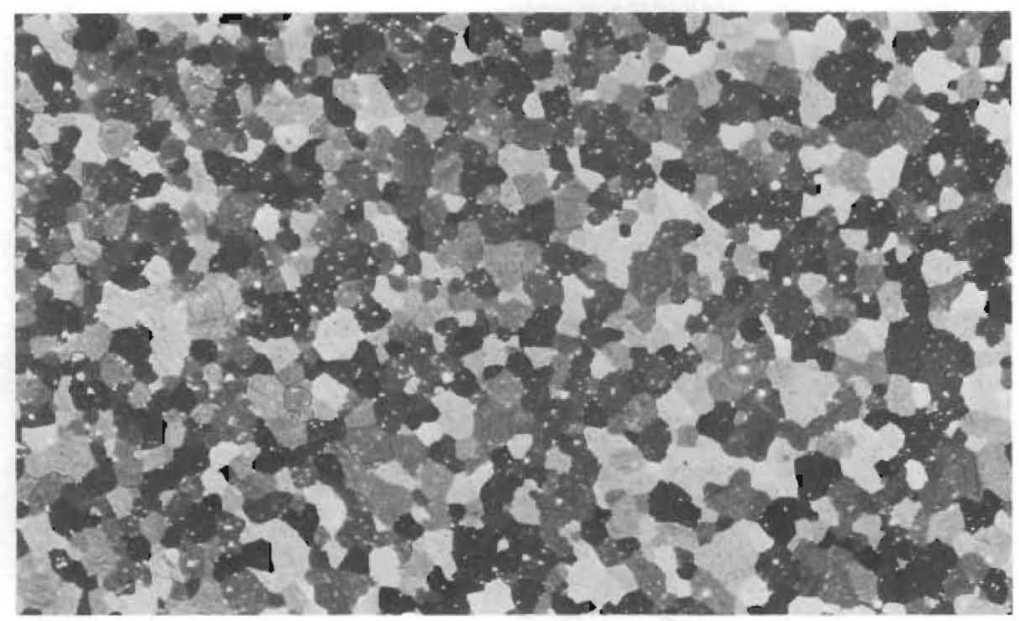

PL (b) Specimen CA

U-180 ppm Fe-90 ppm Si Alpha Rolled plus $7 \mathrm{hr}$ at $643 \mathrm{C}$ (c) Specimen CAB

U-180 ppm Fe-90 ppm Si Alpha Rolled plus $7 \mathrm{hr}$ at $643 \mathrm{C}$ plus 1 hr at $590 \mathrm{C}$ 


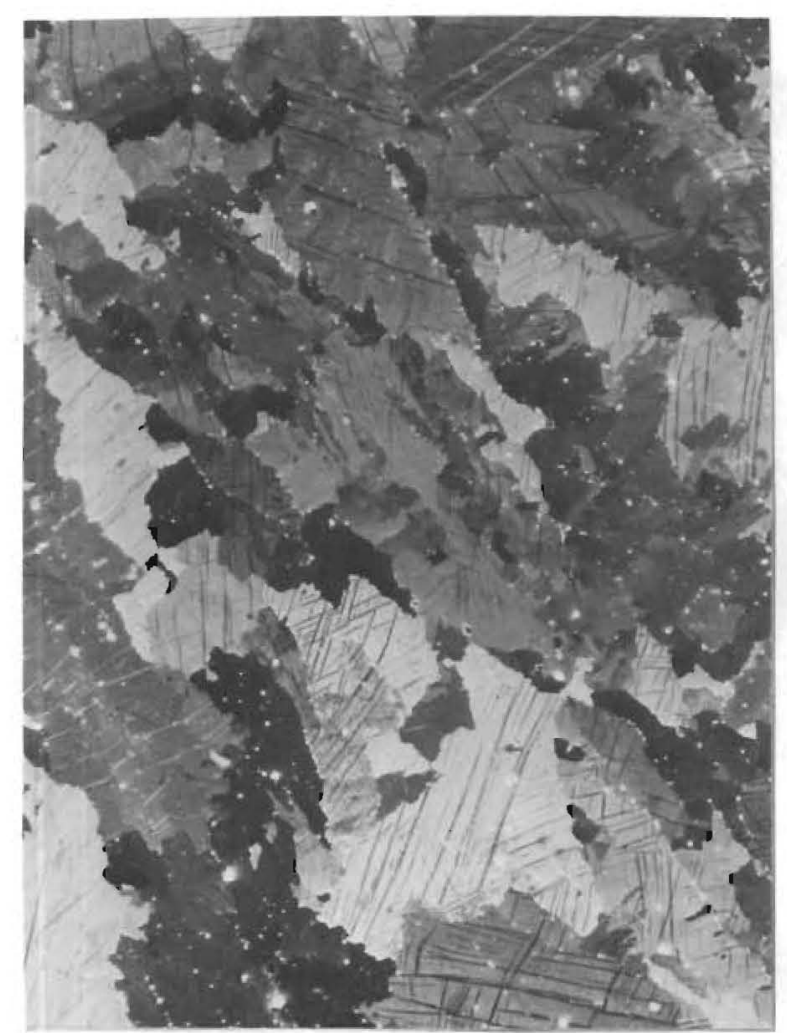

PL

(a) Specimen $\mathrm{CB}$

$100 \mathrm{X}$

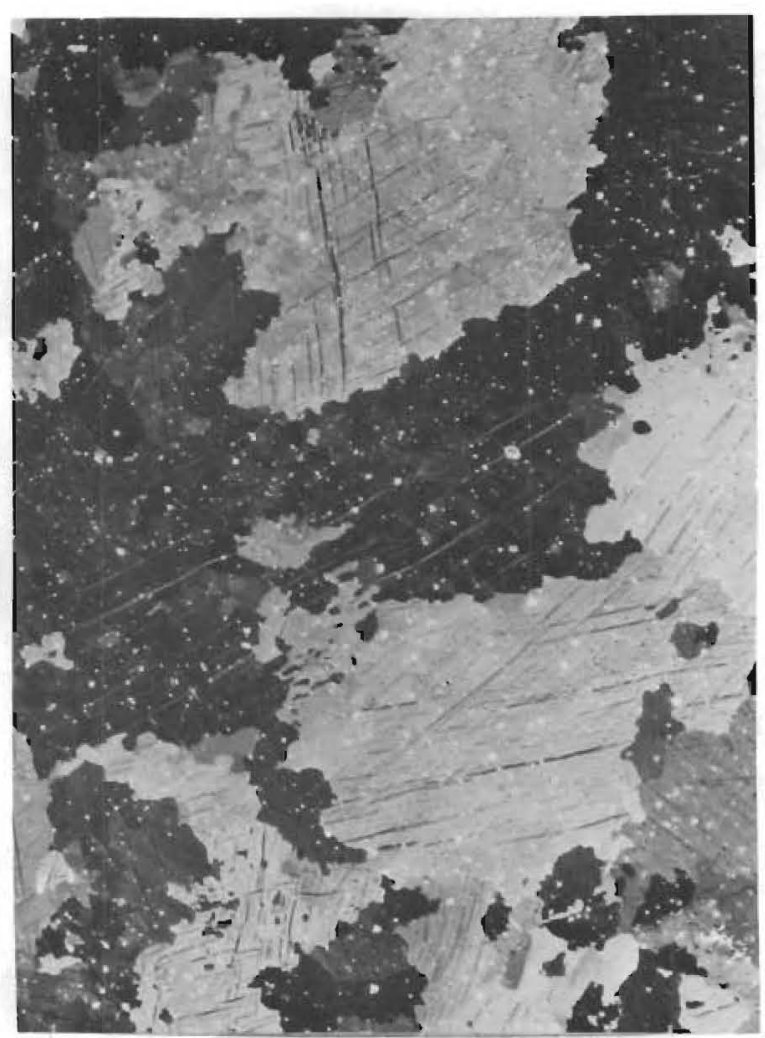

(b) Specimen CBB

$100 \mathrm{X}$

FIGURE 9

(a) U-180 ppm Fe-90 ppm Si Alpha Rolled plus 5 hr at $730 \mathrm{C}$ (b) U-180 ppm Fe-90 ppm Si Alpha Rolled plus $5 \mathrm{hr}$ at $730 \mathrm{C}$ plus $1 \mathrm{hr}$ at $590 \mathrm{C}$

light. Micrographs of specimens $\mathrm{A}$ and $\mathrm{CB}$, for which quantitative data are not yet available, were included with those of $A B, C, C A, C A B$, and $C B B$ for purposes of comparison. The high-purity dingot, material A, is presented in the alpha-rolled and beta solution treated conditions in Figures $6 \mathrm{~A}$ and $6 \mathrm{~b}$, respectively. The alpha-rolled material has small recrystallized grains. The beta solution treated specimen exhibits the typical beta quenched large grains with irregular boundaries.

Material C, with the highest level of alloy addition, is presented in the alpha-rolled, alpha solution treated, and precipitation treated conditions in Figures $8 \mathrm{a}, 8 \mathrm{~b}$, and $8 \mathrm{c}$, respectively. In the alpha-rolled condition, small grains are present which are somewhat irregular due to 
incomplete recrystallization. Solution treatment at $643 \mathrm{C}$ caused some grain growth and removed distortion by annealing out twins and smoothing grain boundaries. Precipitation treatment at $590 \mathrm{C}$ resulted in no additional changes detectable at this magnification.

Material $\mathrm{C}$, in the beta solution treated condition, is shown before and after a $590 \mathrm{C}$ precipitation treatment in Figures $7 \mathrm{a}$ and $7 \mathrm{~b}$, respectively. The structure of this material in the beta quenched condition closely resembles that of the high-purity material in the same heat-treated condition.

Electron Microscopy

Representative electron micrographs of the five specimens which were counted for the quantitative evaluation are presented in Figures 10 through 14 for specimens $\mathrm{C}, \mathrm{CA}, \mathrm{CAB}, \mathrm{CBB}$, and $\mathrm{AB}$, respectively. Frecipitate particles appear on the $\mathrm{UO}_{2}$ shadowed negative carbon replica as light colored globules with a very dark narrow shadow. The dark rim is due to the accumulation of the shadowing material in the cavity of the plastic replica before carbon is deposited on the replica surface. The precipitate particles of specimens $C$ and CA contrast sharply with the background. However, the granular character of the specimen surface is an obvious problem area, particularly for specimens $\mathrm{CAB}, \mathrm{CBB}$, and $\mathrm{AB}$ in which the fine particles are predominant. This texture makes evaluation at magnifications higher than 15,000X impractical because the additional small particles which might otherwise be resolved are camouflaged by the surface texture. Further developments in the area of cathodic etching may help to alleviate this problem.

\section{Quantitative Metallography}

Particle size distribution curves for the five specimens which were successfully prepared for quantitative evaluation are presented in Figure 15. These curves were determined by the methods of Nicholson, as developed above, with input data of observed particle interface diameters on an exponentially increasing scale. The ordinate of each Cell $\mathrm{i}$ is

(Calculated number of particles per cubic centimeter which appeared with observed

$$
y=\frac{\text { radius, } r_{\text {oi }} \text {, in the electron micrograph) }}{\text { (Cell width in units of particle diameter) }}=\frac{\text { particles } / \mathrm{cm}^{3}}{\mu}
$$




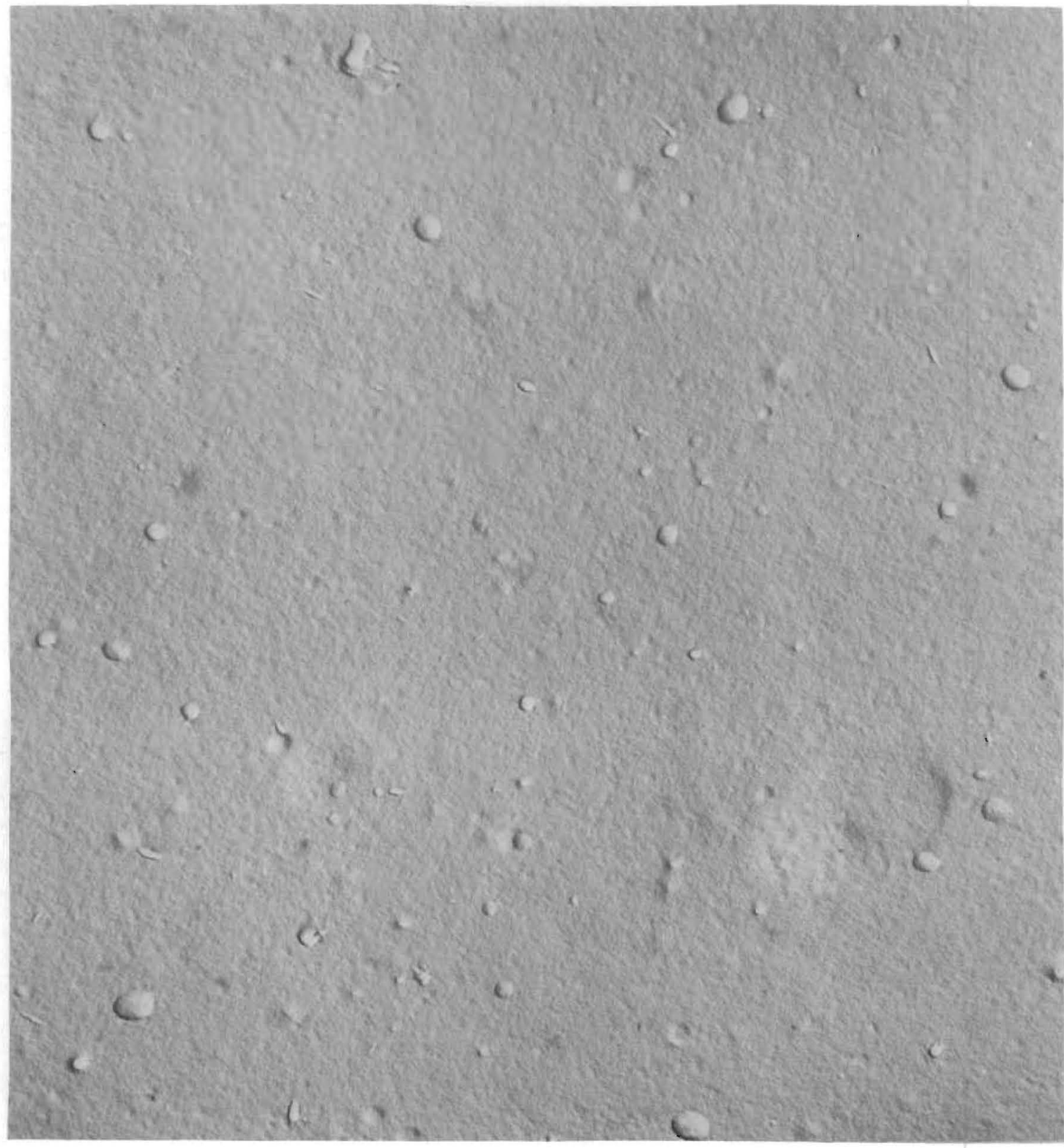

Specimen C

FIGURE 10

U-180 ppm Fe-90 ppm Si, as Alpha Rolled (negative $\mathrm{UO}_{2}$ shadowed carbon replica) 


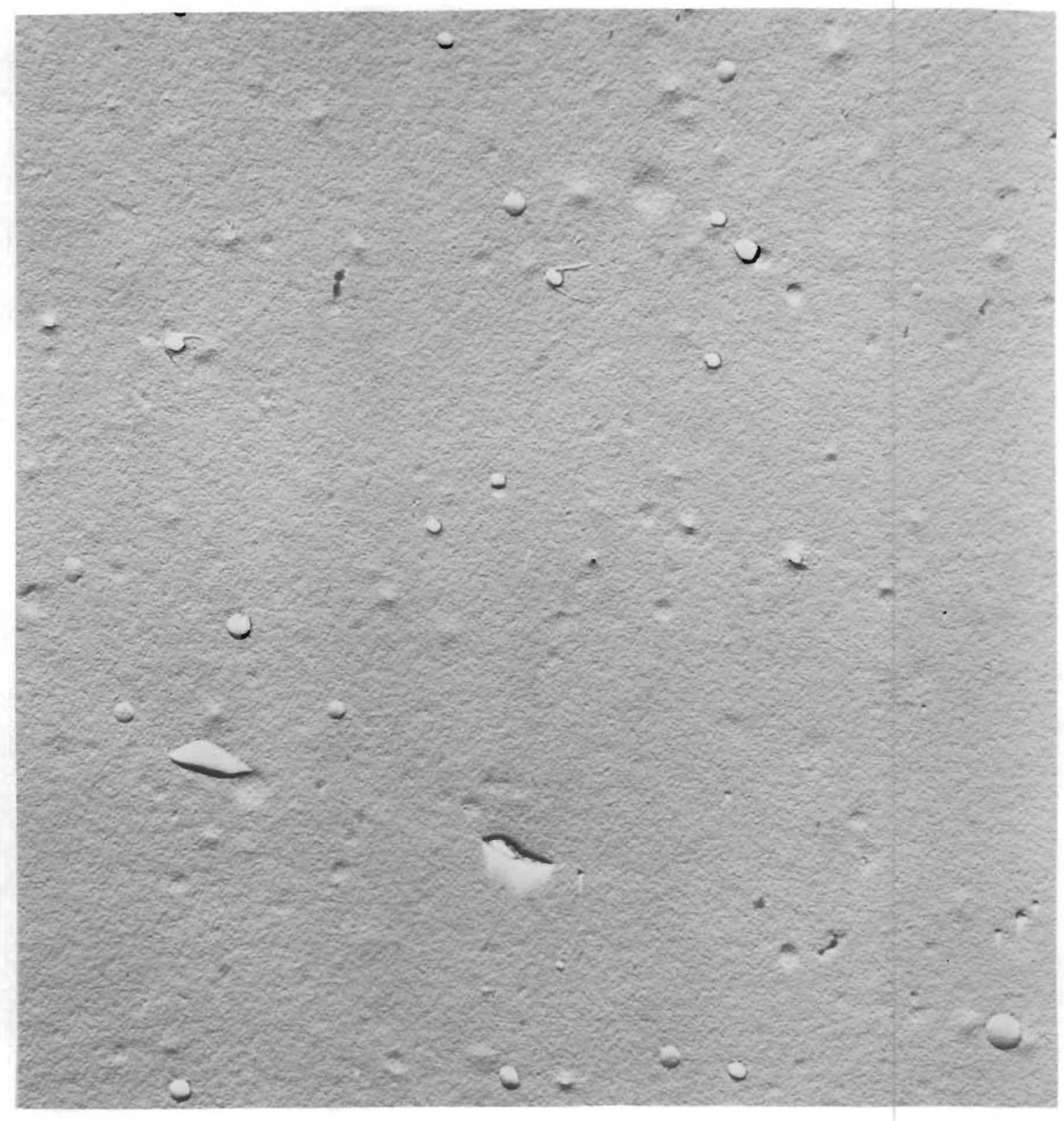

Specimen CA

$7500 x$

FIGURE 11

U-180 Fe-90 ppm Si, Alpha Rolled plus $7 \mathrm{hr}$ at $643 \mathrm{C}$ (negative $\mathrm{UO}_{2}$ shadowed carbon replica) 


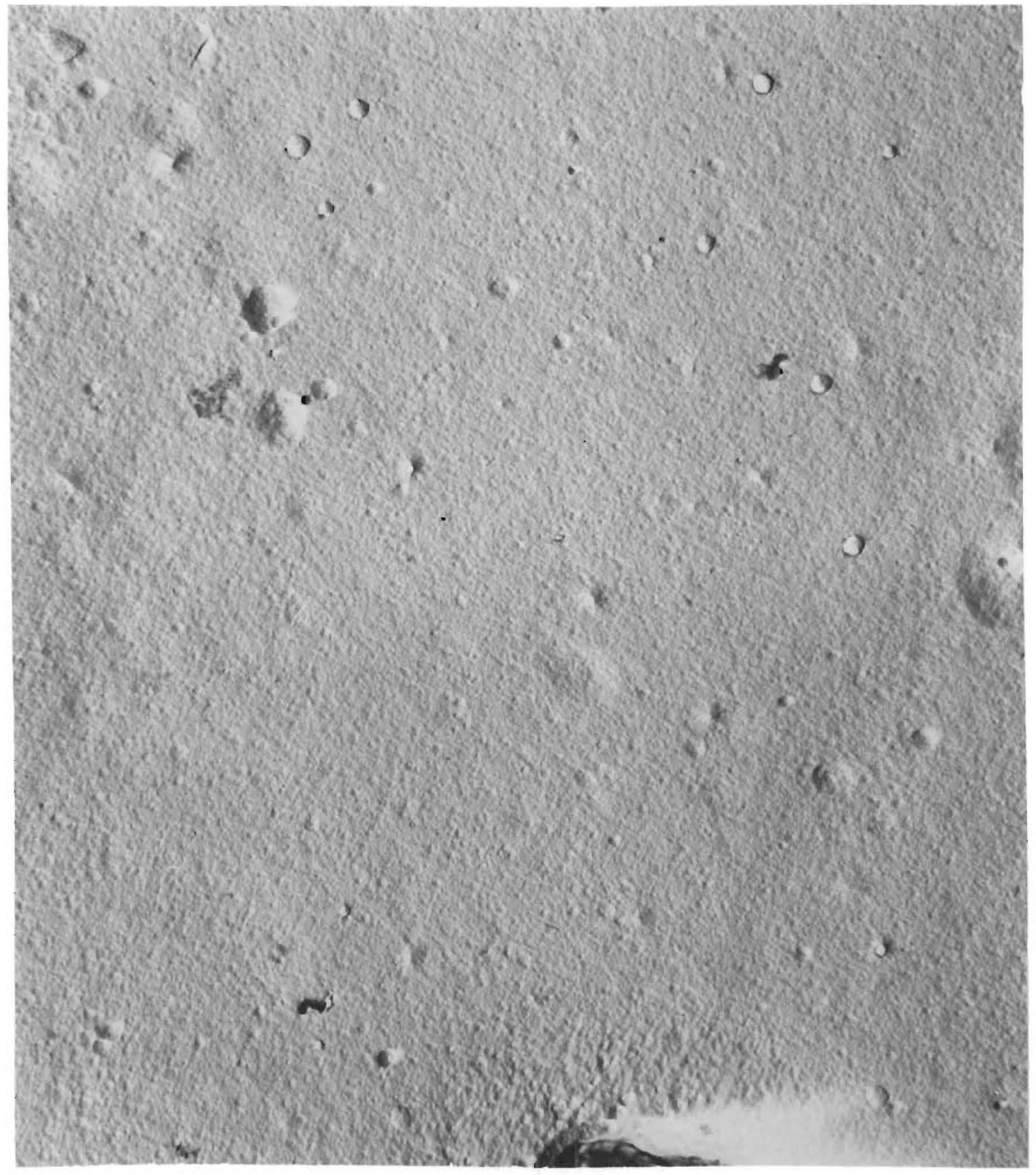

Specimen CAB

$7500 x$

FIGURE 12

U-180 ppm Fe-90 ppm Si, Alpha Rolled plus $7 \mathrm{hr}$ at $643 \mathrm{C}$ plus 1 hr at $590 \mathrm{C}$. (negative $\mathrm{UO}_{2}$ shadowed carbon replica) 


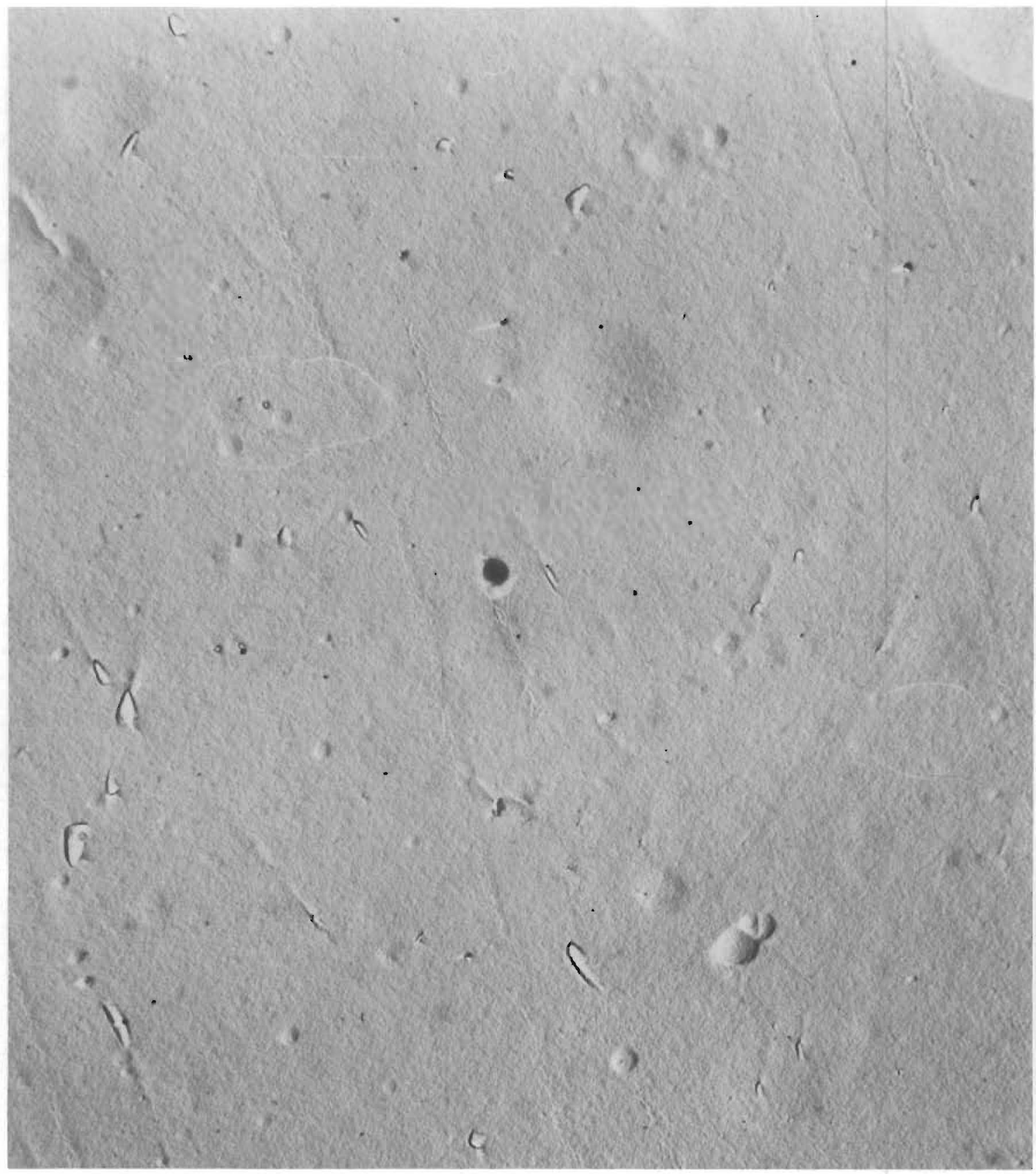

Specimen $\mathrm{CBB}$

$7500 \mathrm{X}$

FIGURE 13

U-180 ppm Fe-90 ppm Si, Alpha Rolled plus 5 hr at $730 \mathrm{C}$ plus $1 \mathrm{hr}$ at $590 \mathrm{C}$. (negative $\mathrm{UO}_{2}$ shadowed carbon replica) 


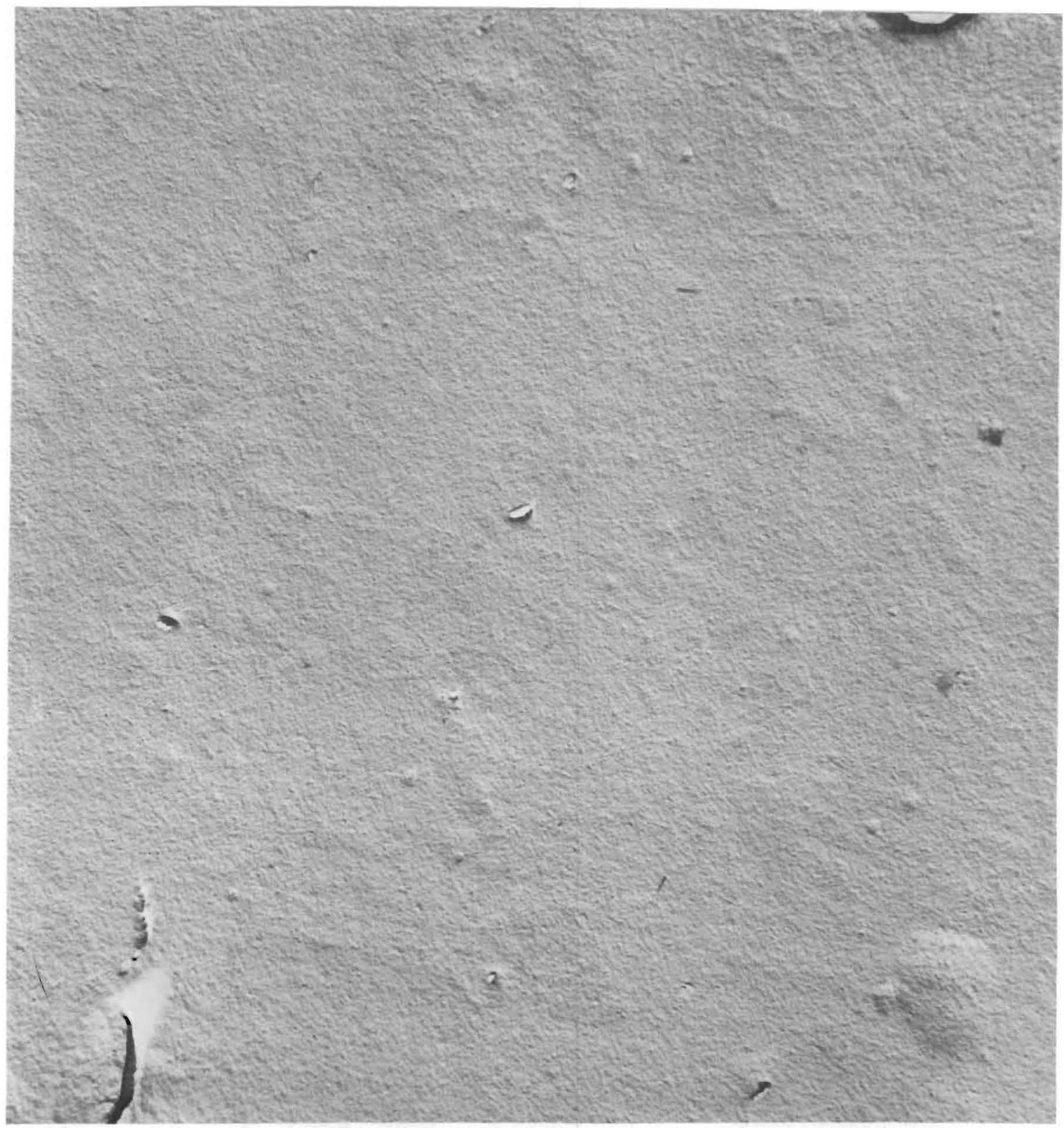

Specimen $A B$

$7500 X$

FIGURE 14

U-45 ppm Fe-20 ppm Si, Alpha Rolled plus $5 \mathrm{hr}$ at $730 \mathrm{C}$ (negative $\mathrm{UO}_{2}$ shadowed carbon replica) 


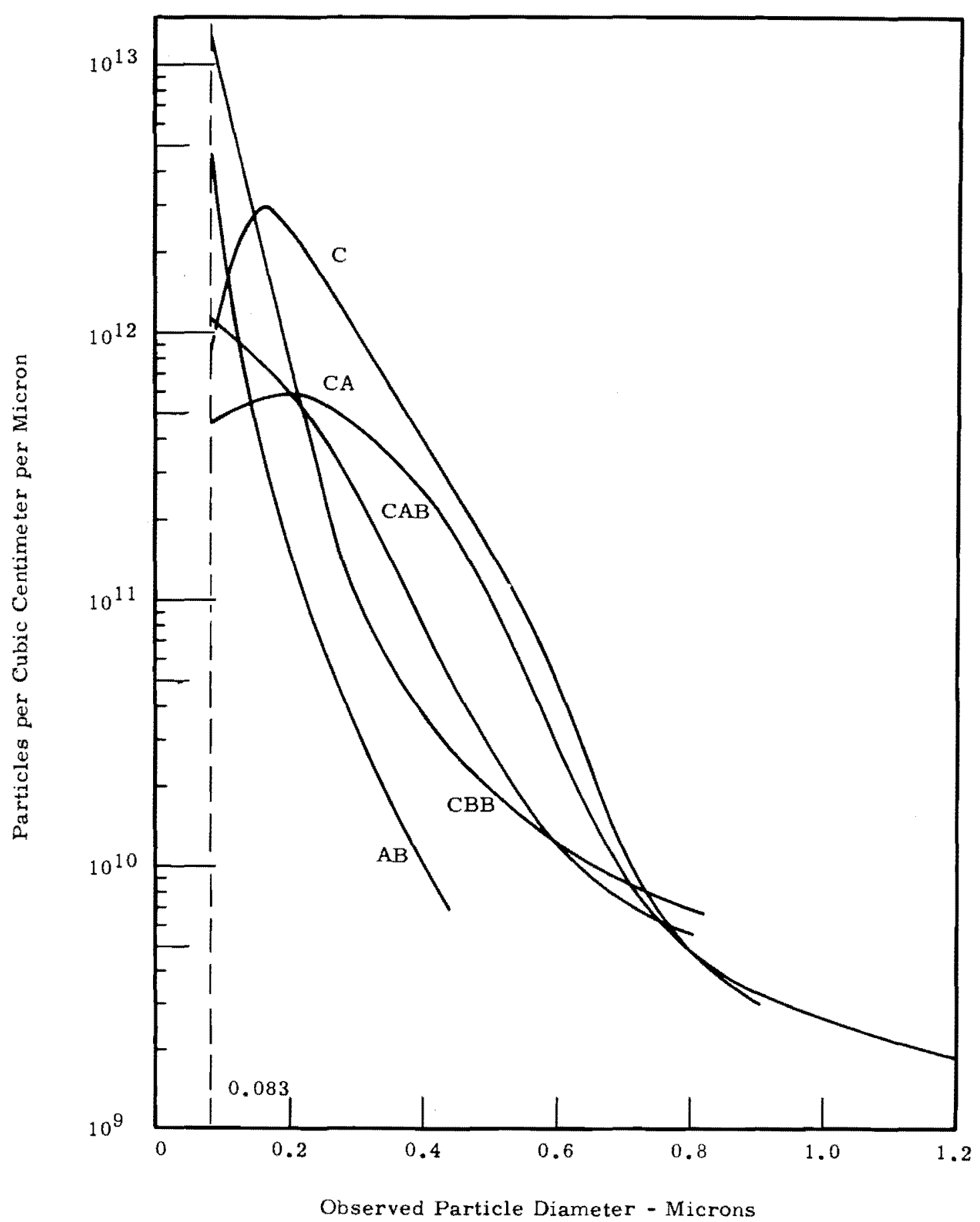

FIGURE 15

Particle Size Distributions of Precipitate Particles in Dilute U-Fe-Si Alloys, as Calculated by the Nichols on Method 
A smooth curve was drawn through these points which were plotted at the cell midpoint of each cell. The curve was fitted to the data on a logarithmic plot because the nature of the distribution was most suited to this type of treatment. The curve may be accepted as an approximation to the curve with ordinates equal to

$$
y_{1}=\frac{\begin{array}{c}
\text { (Calculated number of particles per cubic } \\
\text { centimeter of true radius } \left.r_{i}\right)
\end{array}}{\text { (Cell width in units of particle diameter) }}
$$

The particle size distribution curves are shown replotted in Figure 16 on a linear scale. These curves are the most meaningful, in that they may be integrated over any arbitrary range of particle size to yield directly the number of particles per cubic centimeter in that size range. Therefore, important information concerning the effect of heat treatment on the dispersed phase can be gained by observing the area beneath the respective curves. Specimen $\mathrm{C}$, according to the Battelle-Northwest analysis, contained approximately $180 \mathrm{ppm}$ iron and 90 ppm silicon. This specimen, which is in the alpha-rolled condition, exhibits a density peak at an observed particle diameter of $0.16 \mu$ and a total integrated particle density of $5.15 \times 10^{11}$ particles $/ \mathrm{cm}^{3}$ (Table III). Curve CA

\section{TABLE III}

TOTAL PARTICLE DENSITY OBTAINED FROM GRAPHICAL INTEGRATION Of DENSITY CURVES

\section{$\underline{\text { Specimen }}$}

$\mathrm{C}$

$\mathrm{CA}$

$\mathrm{CAB}$

$\mathrm{CBB}$

$\mathrm{AB}$

$$
\begin{aligned}
& \text { Particles } / \mathrm{cm}^{3} \\
& 5.15 \times 10^{11} \\
& 1.88 \times 10^{11} \\
& 1.57 \times 10^{11} \\
& 4.15 \times 10^{11} \\
& 1.11 \times 10^{11}
\end{aligned}
$$

represents the result of solution treating the alph-rolled specimen in the high alpha range. Apparently, either the majority of the fine particles were taken into solution or agglomeration took place. While the peak remains at approximately the same particle size, it is significantly reduced in height. The total 


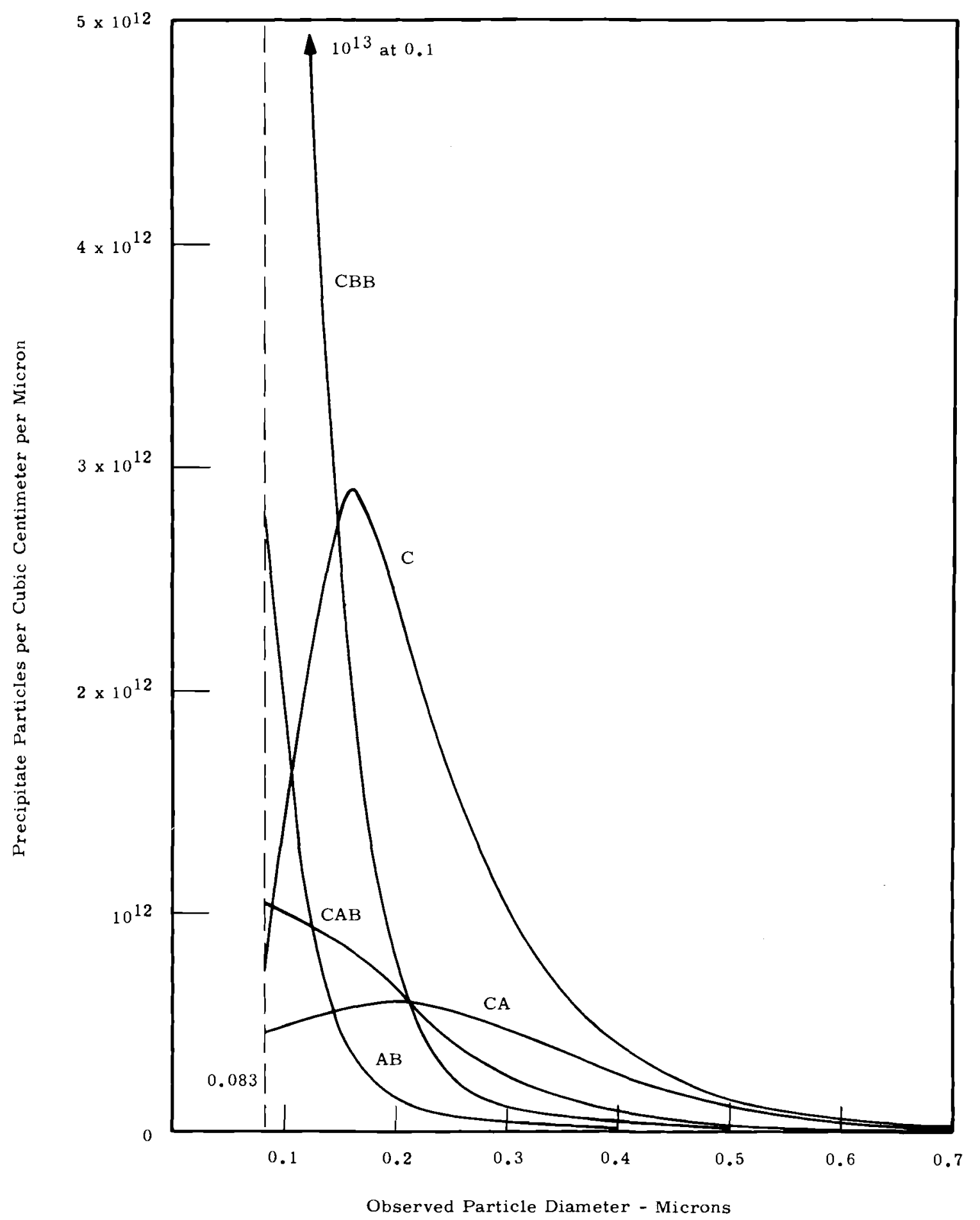

FIGURE 16

Linear Plot of Particle Size Distributions of Precipitate Particles in Dilute U-Fe-Si Alloys, as Calculated by the Nicholson Method 
integrated particle density has been reduced to $1.88 \times 10^{11}$ particles $/ \mathrm{cm}^{3}$. Precipitation treatment at $590 \mathrm{C}$ of the alpha solution treated material results in the distribution given by curve CAB. The larger particles, above $0.2 \mu$, have undergone further dissolution while some finer particles have precipitated. The total integrated particle density, however, has dropped to $1.57 \times 10^{11}$ particles $/ \mathrm{cm}^{3}$, less than the solution treated specimen. Apparently, the alpha range solution treatment is inadequate. The density curve of specimen $\mathrm{CBB}$, which was alpha-rolled and solution treated in the beta range, followed by a precipitation treatment at $590 \mathrm{C}$, emphasizes the benefits of a sufficiently high solution treatment. While the total integrated particle density is only $4.15 \times 10^{11}$ particles $/ \mathrm{cm}^{3}$, slightly less than that of specimen $C$, the diameter of the majority of the particles is less than $0.2 \mathrm{~m}$. Because the peak occurs below the resolution point, the actual total is certainly significantly higher. As the fine particles are presumed to have a greater effect on irradiation behavior it is important that the present techniques be improved to include the smaller particles in the analysis. Specimen AB was included in this initial presentation strictly on the basis of availability, but it makes an interesting comparison with the higher alloy specimens. This material contains only 45 ppm Fe and 20 ppm Si according to the BattelleNorthwest analysis. This specimen, which was observed in the beta solution treated condition, has a total integrated particle density of $1.11 \times 10^{11}$, less than any of the higher alloy specimens, However, like the other beta solution treated specimen, it also has a density peak which is below the resolution point. This is an indication that the quenching rate is not fast enough to hold the intermetallic constituents in solution.

The calculated volume fraction of precipitate particles for the respective specimens is presented in Table IV. For an alloy content of $180 \mathrm{ppm}$ Fe and $90 \mathrm{ppm} \mathrm{Si}$, the maximum possible volume fraction, i.e., no solubility, would be 0.008 . However, some solid solubility is expected and the volume fraction should be less than maximum; while the presence of intermetallics and compounds formed by other impurity atoms on the otherhand should lead to a higher value. Table IV shows that volume 
BNWL-30

TABLE IV

TOTAL CALCULATED VOLUME FRACTION

OF PRECIPITATE PARTICLES

$\underline{\text { Specimen }}$

$\mathrm{C}$

CA

$\mathrm{CAB}$

$\mathrm{CBB}$

$\mathrm{AB}$
Volume Fraction

0.0126

0.0106

0.0038

0.0046

0.0022

fractions both above and below this level were encountered. Apparently, specimens $\mathrm{C}$ and $\mathrm{CA}$ contained a significant quantity of these additive contributions. This was particularly true of CA which has an unreasonably high calculated volume fraction due to several particles greater than $1 \mathrm{~m}$ appearing in the counted data. With the exception of these noted discrepancies, the volume fraction calculations are in line with expectations.

Figure 17 presents a comparison of the results of three different methods of calculation of the particle size distribution curve for specimen $\mathrm{C}$, for which the particle count of 306 particles was greater than any of the other specimens counted. All give approximately the same shape of curve, with the Johnson-Saltykov method yielding slightly higher numbers than the Schwartz. The Nicholson calculation, however, lies significantly beneath the other two, a factor of approximately two less than the JohnsonSaltykov.

Figure 18 presents a similar comparison for a specimen of spherodized $1.10 \%$ carbon steel. Curve $A$ is the result of the Nicholson calculation of data in which particles appeared over a range of 39 cells within the 48 cell measurable range having exponentially distributed diameters. The same data fitted into 25 cells having diameters distributed on the linear scale as calculated by the Nicholson method is represented by curve $B$. The only significant difference between the two is the lack of a maximum in curve $B$ due to the loss of resolution of the curve in the small particle range, which was incurred by going from the exponential to the linear distribution of particle diameters. 


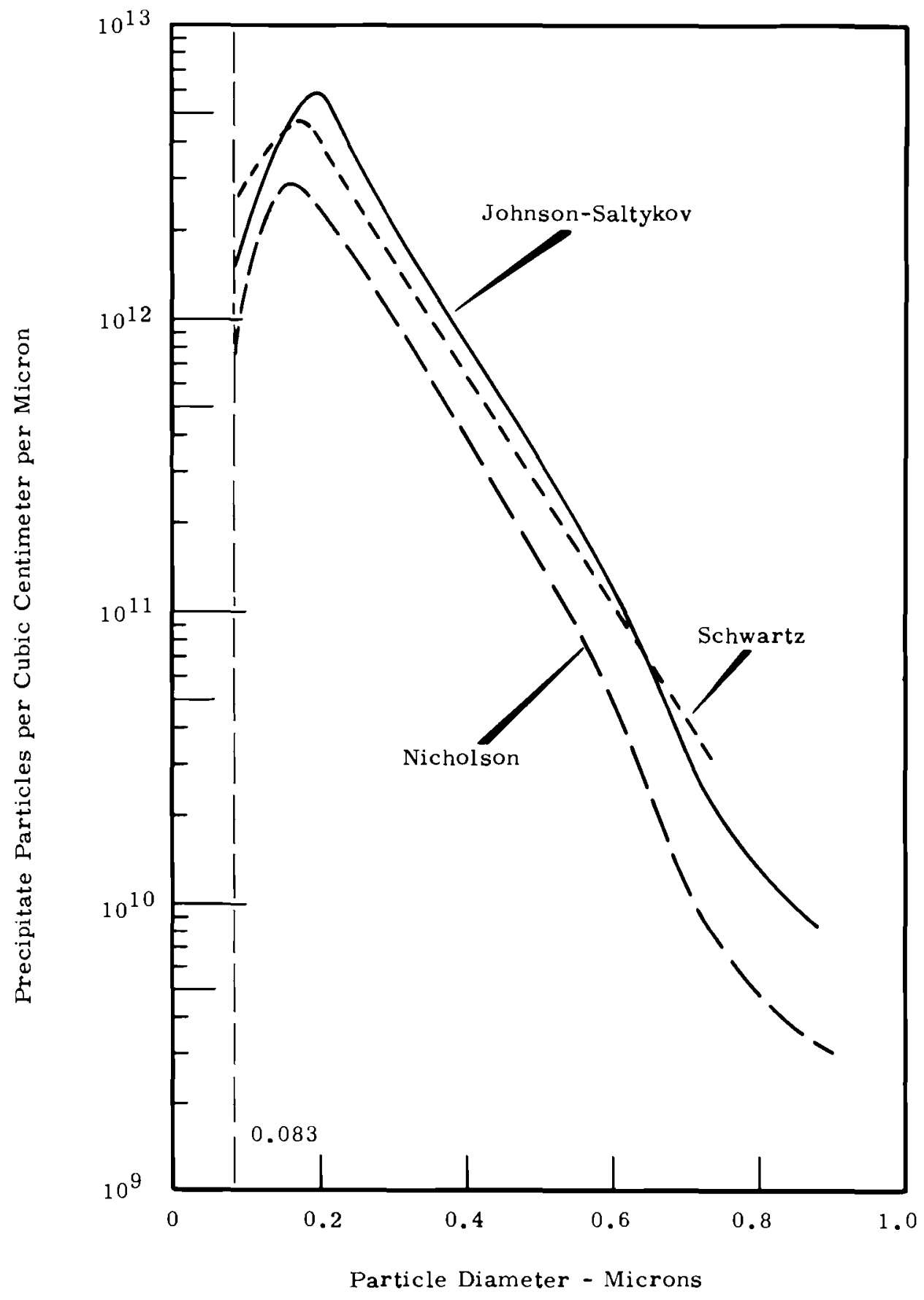

\section{FIGURE 17}

Comparison of Results Yielded by Different Methods of Calculating Particle Size Distribution of Precipitate Particles in Alpha-Rolled U-180 ppm Fe-90 ppm Si Alloy 


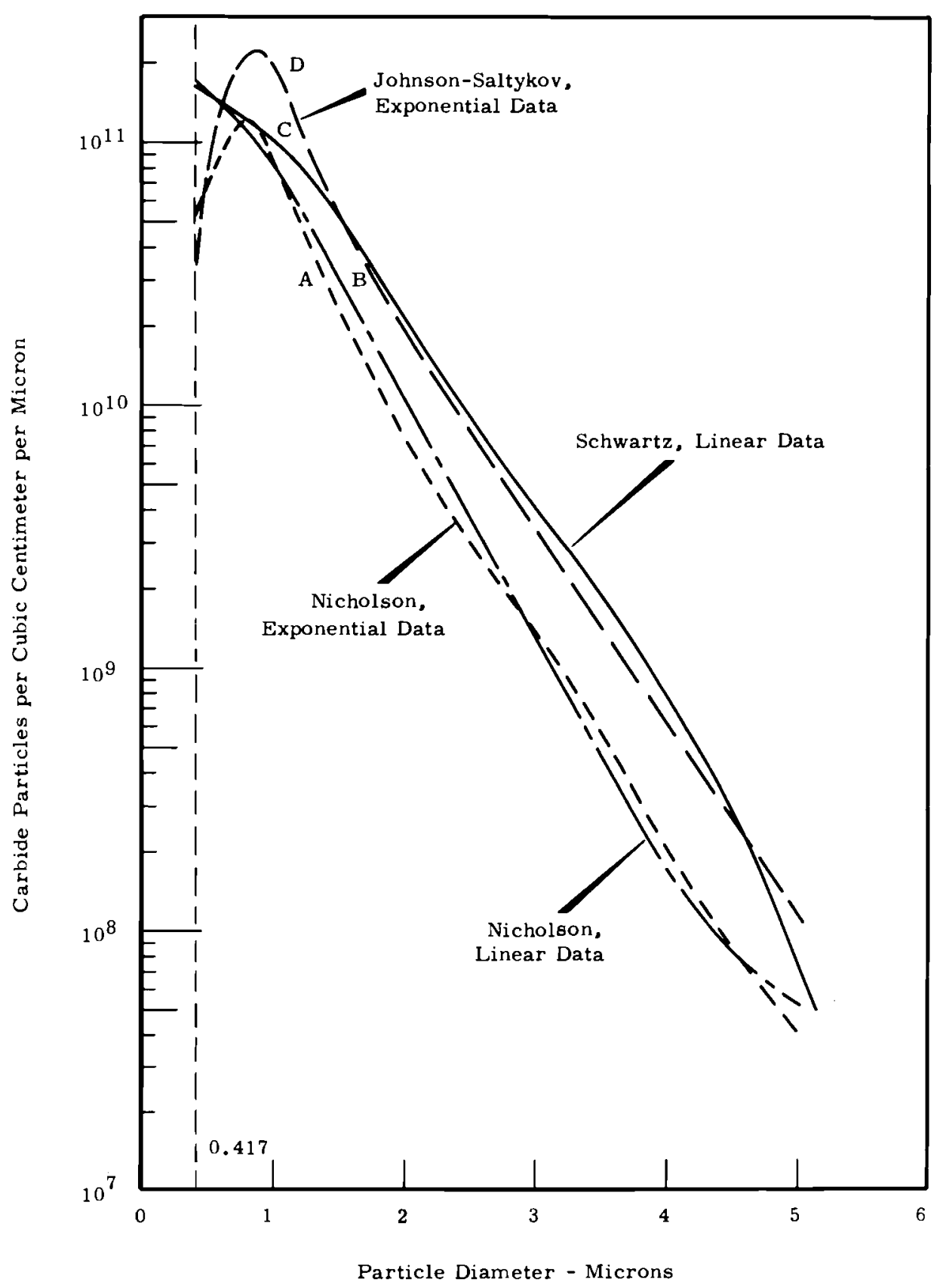

FIGURE 18

Comparison of Results Yielded by Different Methods of Calculating Particle Size Distribution of Carbides in Spherodized 1. 10\% Carbon Steel 
Curve $\mathrm{C}$ is the result of a Schwartz calculation of the same data which was distributed over ten linearly related cells. The curve shape is similar to that of the Nicholson curve $B$ which is based on a linear distribution of particle sizes, although the curves are displaced from each other over most of the region. The Johnson-Saltykov treatment of the same data over the 39 cells of curve A results in the distribution of curve D. The shape of the smoothed curve is almost identical to that of curve A. This result, however, is also displaced upward by approximately a factor of two from the Nicholson curve.

\section{$\underline{\text { DISCUSSION }}$}

The interrelationships between the various calculated distributions point out some questions which should be resolved in order to provide a firm foundation for further work. The Nicholson calculation estimates the density of particles in each cell which present a particular observed radius in the electron micrograph. On the other hand, the Johnson-Saltykov and Schwartz methods estimate the density of particles of a particular true diameter. Therefore, the Nicholson curve should be of somewhat different shape than the others. Particularly, it should yield a high-density of particles in the small particle region. In addition, the factor of two difference between the Nicholson and other methods in Figures 17 and 18 is also, at this point, unexplained. However, it should be noted that in a distribution which can readily be changed by one or more factors of ten by an adjustment in heat treating schedule, a factor of two is not necessarily significant.

The benefits of the exponential distribution of cell mean diameters is emphasized by curves $\mathrm{B}$ and $\mathrm{C}$ of Figure 18, in which the peak of the distribution in the fine particle region is not resolved. Increasing the number of cells for the given diameter range would, of course, resolve it but since there is not need for a greater number in the large particle region, the exponential distribution is the best approach. 
It is of interest to compare the precipitated particle distribution of Figure 17 with the carbide particle distribution of Figure 18. Although considerable differences exist between the two two-phase situations, the shapes of the distribution curves are very similar.

The calculated distributions of specimens $\mathrm{CAB}, \mathrm{CBB}$, and $\mathrm{AB}$, in Figure 15 indicate the necessity of lowering the nonzero resolution point in order to bring the peaks of the distributions of these alloys into the $r$ ange of investigation. Making measurements on the finer particles requires micrographs of higher magnification, i.e., 30, 000X or 60,000X. In order to make this possible it will be necessary to further develop the surface preparation technique either by further development of the electrolytic process or by vacuum cathodic etching. Such further developments in surface preparation and accompanying reduction of the resolution point should make it possible to select the optimum combination of heat treatments to ga in a high-density of fine particles in the U-Fe-Si system, and also allow the technique to be extended to other systems.

\section{ACKNOWLEDGEMENTS}

The authors $w$ ish to acknowledge the assistance of the following individuals: Dr. T. K. Bierlein for his invaluable guidance; Professor M. J. Sinnott of the University of Michigan for his encouragement and advice; Dr. W. L. Nicholson and J. Figg of Applied Mathematics for helpful technical discussions and computer calculations; D. J. Bailey for the electron microscopy; A. M. Bloomstrand for the work on the Particle Size Analyzer; and R. H. Beauchamp, I. J. Robertson, and M. H. Brady for their contributions to the metallography. 


\section{REFERENCES}

1. R. G. Bellamy. "The Swelling of Alpha-Uranium Under Neutron Irradiation to $0.7 \%$ Burnup, "Inst. of Metals Symposium on Uranium and Graphite, Paper no. 8. 1962 .

2. D. Kramer and W. V. Johnston. "Postirradiation Annealing of UraniumMolybdenum Ternary Alloys," J. Nuc. Matls., vol. 9, pp. 213-215. July, 1963.

3. R. W. Anderson. Progress Report to Savannah River, NMI-7252. July 31, 1962.

4. W. L. Nicholson. Unpublished Data.

5. K. A. Brownlee. Statistical Theory and Methodology in Science Engineering, J. Wiley and Sons, New York. 1960.

6. F. N. Rhines and R. T. DeHoff. Quantitative Metallography, McGraw-Hill Book Co. (To be Published). 


\section{INTERNAL DISTRIBUTION}

\section{Copy Number}

$\begin{array}{ll}1 & \text { F. W. Albaugh } \\ 2 & \text { T. K. Bierlein } \\ 3 & \text { F. E. Bowman } \\ 4 & \text { J. L. Brimhall } \\ 5 & \text { J. J. Cadwell } \\ 6 & \text { D. H. Curtis } \\ 7 & \text { T. W. Evans } \\ 8 & \text { J. W. Goffard } \\ 9 & \text { A. E. Guay } \\ 10 & \text { L. A. Hartcorn/R. L. Hales } \\ 11 & \text { R. S. Kemper } \\ 12 & \text { H. E. Kissinger } \\ 13 & \text { J. J. Laidler } \\ 14 & \text { G. A. Last } \\ 15-24 & \text { R. D. Leggett } \\ 25 & \text { M. C. Leverett } \\ 26 & \text { M. Lewis } \\ 27 & \text { B. Mastel } \\ 28 & \text { J. E. Minor } \\ 29 & \text { T. D. Naylor } \\ 30 & \text { R. D. Nelson } \\ 31 & \text { W. L. Nicholson } \\ 32 & \text { R. Todd } \\ 33 & \text { J. C. Tverberg } \\ 34 & \text { J. W. Weber } \\ 35-39 & \text { Technical Information Files } \\ 40-41 & \text { Technical Publications }\end{array}$

\section{EXTERNAL DISTRIBUTION (Special)}

Number of Copies

1

1

2

1

1

Eaton Manufacturing Company, Detroit Michigan

Attn: Y. E. Smith

Northwestern University, Evanston, Illinois

Attn: K. N, Woods

Richland, Operations Office

Attn: Technical Information Library

$R$. K. Sharp

Union Carbide Corporation (ORNL)

Attn: T. M. Kegley, Jr.

University of Michigan

Attn: M, J. Sinnett 